\title{
Morphological diagnoses of higher taxa in Ophiuroidea (Echinodermata) in support of a new classification
}

\author{
Timothy D. O'HARA ${ }^{1}$, Sabine STÖHR ${ }^{2, *}$, Andrew F. HUGALL ${ }^{3}$, \\ Ben THUY ${ }^{4} \&$ Alexander MARTYNOV ${ }^{5}$ \\ ${ }^{1,3}$ Marine Invertebrates, Sciences, Museum Victoria, GPO Box 666, \\ Melbourne, Victoria 3000, Australia. \\ ${ }^{2}$ Swedish Museum of Natural History, Department of Zoology, Box 50007, \\ 10405 Stockholm, Sweden. \\ ${ }^{4}$ Section Paléontologie, Musée national d'Histoire naturelle du Luxembourg, \\ 24 Rue Münster, 2160 Luxembourg. \\ ${ }^{5}$ Zoological Museum, Moscow State University, Bolshaya Nikitskaya Str. 6, \\ Moscow, 125009, Russia. \\ *Corresponding author: sabine.stohr@nrm.se \\ 1Email: tohara@museum.vic.gov.au \\ ${ }^{3}$ Email: ahugall@museum.vic.gov.au \\ [4Email: ben.thuy@mnhn.lu \\ ${ }^{5}$ Email:martynov@zmmu.msu.ru \\ ${ }^{1}$ urn:lsid:zoobank.org:author:9538328F-592D-4DD0-9B3F-7D7B135D5263 \\ ${ }^{2}$ urn:lsid:zoobank.org:author:412800EB-AACE-4313-9810-61F89B740405 \\ ${ }^{3}$ urn:lsid:zoobank.org:author:EF587E93-9687-43E4-87F6-F761260C3ADA \\ ${ }^{4}$ urn:Isid:zoobank.org:author:04186A8C-3F0D-485E-834A-08414A217ACA \\ ${ }^{5}$ urn:lsid:zoobank.org:author:41376523-28E6-4EFA-B1A7-AFC3AE1A9727
}

\begin{abstract}
A new classification of Ophiuroidea, considering family rank and above, is presented. The new family and superfamily taxa in O'Hara et al. (2017) were proposed to ensure a better readability of the new phylogeny but are unavailable under the provisions of the ICZN. Here, the morphological diagnoses to all 33 families and five superfamilies are provided. Ten new families, Ophiosphalmidae fam. nov., Ophiomusaidae fam. nov., Ophiocamacidae fam. nov., Ophiopteridae fam. nov., Clarkcomidae fam. nov., Ophiopezidae fam. nov., Ophiernidae fam. nov., Amphilimnidae fam. nov., Ophiothamnidae fam. nov. and Ophiopholidae fam. nov., are described. The family Ophiobyrsidae Matsumoto, 1915, not yet discovered in the previous publication, is added, based on new molecular data. A new phylogenetic reconstruction is presented. Definitions of difficult-to-apply morphological characters are given.
\end{abstract}

Keywords. Taxonomy, brittle-stars, morphology, phylogeny, nomenclature.

O'Hara T.D., Stöhr S., Hugall A.F., Thuy B. \& Martynov A. 2018. Morphological diagnoses of higher taxa in Ophiuroidea (Echinodermata) in support of a new classification. European Journal of Taxonomy 416: 1-35. https://doi.org/10.5852/ejt.2018.416 


\section{Introduction}

In their new phylogeny of the Ophiuroidea, O'Hara et al. (2017) named the new families suggested by their phylogeny for the sake of readability but deferred the morphological delimitation of the new families, and supplied no diagnoses, leaving the proposed names unavailable in that publication. The new classification was presented in an electronic supplement and as such nomenclaturally unavailable (Krell 2015) with respect to ranks that are governed by the ICZN (family group names and below).

Here, we provide the diagnoses, required by the ICZN, to make the new family names available and valid. In addition to newly formed families, several previously proposed but later synonymized families are resurrected. We reconsidered a few decisions on the composition of some families, compared to the preliminary classification presented in O'Hara et al. (2017). A new monophyletic clade corresponding to the Ophiobyrsidae Matsumoto, 1915 was identified with new molecular data and morphological characters. Of the 256 currently recognized genera (Stöhr et al. 2017), many remain to be analysed and possibly revised, which may affect their final placement in the classification. New family-level clades may also be discovered in the future. With respect to previously existing names, it should be noted that the concepts of many of the taxa delimited herein differ considerably from the concepts held by the original authors of these taxon names. Meier (2017) stressed the difference between taxon naming and taxon delimitation, the former being a technical housekeeping exercise and the latter being hypothesis driven. This difference becomes quite obvious in the work presented here. For the sake of nomenclatural stability, naming conventions require that existing names are preserved, even when the concept associated with that name changes beyond recognition. Taxon concepts are clearly scientific hypotheses of evolutionary relationships, and may change over time, being tested against new data. Phrases such as "taxon A is polyphyletic/paraphyletic" refer to the concept of the respective taxon, i.e., the assortment of genera included in a family, or species included in a genus. They do not question the monophyly of a clade but the application of the name to a component of the clade.

\section{Material and methods}

\section{Data collection}

This study is the result of years of taxonomic work and data collection by the authors and therefore the material used comes from a variety of sources. Specimens were sourced from museum collections all over the world, in particular from the Swedish Museum of Natural History (Stockholm), the Zoological Museum of Moscow State University, the Muséum national d'Histoire naturelle (Paris), as well as from the authors' personal research material. The brittle stars were examined, dissected, photographed, subjected to scanning electron microscopy, and used for molecular work. The data used here were produced and accumulated over the past 20 years, originally for other projects, published in part (Stöhr 2005; Stöhr \& Segonzac 2005; O’Hara \& Stöhr 2006; Stöhr, Conand \& Boissin 2008; Stöhr, Boissin \& Chenuil 2009; Martynov 2010a, 2010b; Stöhr \& Muths 2010; Stöhr 2011; Thuy \& Stöhr 2011; Thuy 2013; Thuy \& Stöhr 2016; Stöhr \& Martynov 2016; O’Hara et al. 2017)

We analysed original images from our respective collections, as well as text and illustrations from original descriptions of genera and families (for a complete list of original works see Appendix A), and from other literature (Paterson 1985; Martynov 2010b; Thuy \& Stöhr 2011; Pineda-Enriquez et al. 2014), to identify synapomorphies of the various taxa, diagnosed below. Species were identified using identification keys (Mortensen 1927; Clark \& Rowe 1971; Paterson 1985), and recent revisions and new descriptions (O'Hara et al. 2004; O'Hara \& Stöhr 2006; Benavides-Serrato \& O'Hara 2008; Martynov \& Litvinova 2008; Okanishi \& Fujita 2009; Okanishi et al. 2011a, 2011b; Stöhr 2011; Okanishi \& Fujita 2011; Okanishi et al. 2013; Pineda-Enriquez et al. 2014; Baker 2016). One family, Ophiobyrsidae Matsumoto, 1915, not included in O'Hara et al. (2017), but presented here, was identified by molecular 
methods and phylogenetic analyses as described in that publication, and diagnosed morphologically here. This slightly changed phylogenetic reconstruction is shown in Fig. 1.

Only a limited number of genera and species has been subjected to detailed morphological examination so far. Particularly the characteristics of the internal skeleton are unknown for the majority of the about 2100 described species (Stöhr et al. 2017). Although O'Hara et al. (2017) collected molecular data for more than a quarter of all known species, within- and between-family relationships may change when more data are available. The diagnoses provided herein are based foremost on some of the characters presented by the type species of each family (Thuy \& Stöhr 2016), to comply with nomenclatural rules, although the type species are in some cases rather specialized with many novelties that are absent in other members of the same family (e.g., Astrophiura Sladen, 1879). Such novelties or autapomorphies of genera were excluded from the diagnosis of a family to accommodate a wider range of included genera. Other genera than the type genus are included based on molecular data alone (O'Hara et al. 2017), when the available morphological data are insufficiently known. Many rarely collected species are still unavailable for study, and strongly paedomorphic species are difficult to place without molecular data due to their aberrant morphology suggesting false homologies that are actually homoplasies, as well as pseudoplesiomorphies (Stöhr \& Martynov 2016). The following diagnoses present synapomorphies that support the monophyly of each taxon, and characters that distinguish the families within a higher taxon. We do not provide full descriptions for each family, because at this point it is unclear which characters are common to all members (genera) of a family, in addition to the synapomorphies so far identified. Some families are surprisingly heterogeneous in morphology but clearly monophyletic according to our molecular data (O'Hara et al. 2017). Characters may have been reduced during evolution within a family and other characters may have appeared as novelties in one or more genera. The phylogenetic relationships on lower taxonomic level (below family rank) will be the subject of future molecular and morphological studies.

\section{Character definitions}

Many significant characters require dissection and examination of micromorphology, sometimes only visible by scanning electron microscopy. For the purpose of routine identifications this is unfortunate but previous attempts at reconstructing the ophiuroid phylogeny were clearly hampered by the almost exclusive use of external and macromorphological characters, as has been shown by the most recent morphological phylogenetic analysis (Thuy \& Stöhr 2016). The terminology used for the ophiuroid skeleton has varied widely over the last two centuries. Stöhr et al. (2012) proposed a standardized list of terms, but clear definitions are hampered by our limited understanding of ophiuroid morphology. Recent work (Martynov 2010b; Thuy \& Stöhr 2011, 2016) has provided insights that allow us to refine existing terms and define new structures. Here we provide our definitions for some of the more difficult or confusing characters used, with example illustrations (Fig. 2A-J).

Disc scales and plates (Fig. 2A) are terms that are often used in a random fashion, perhaps based on size, scales being considered smaller than plates. Instead, the term 'plate' should be used for external disc or arm ossicles with fixed position and exact number, which makes them individually identifiable (e.g., primary disc plates, radial shields, dorsal, ventral and lateral arm plates) and predictable during ontogeny (Sumida et al. 1998; Stöhr 2005). Some internal ossicles are also called plates, e.g., oral and genital plates. In contrast, scales are found mainly on the disc, rarely on the arms, and they cannot be identified individually, their number varies between individuals and ontogenetic stages and they do not always appear in the exact same position. In species with reduced numbers of disc scales, these can become individually recognizable, fixed in position and number, and predictable in ontogeny. There is thus a certain flexibility in these terms that cannot be eliminated. 


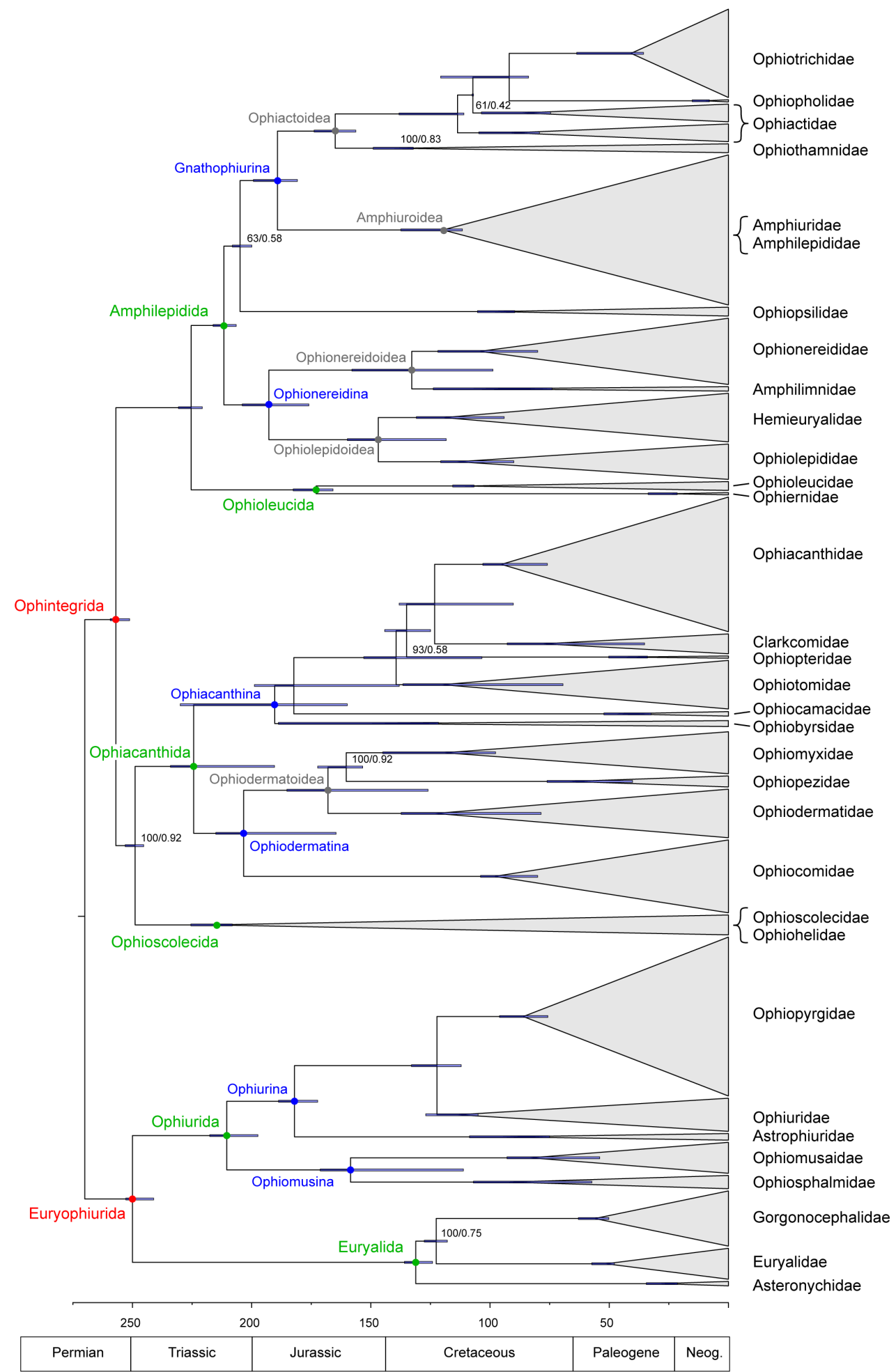

Fig. 1. Summary phylogenetic tree of the ophiuroid higher taxonomy. Modified from O'Hara et al. (2017: fig. 1), with Ophiobyrsidae included based on O'Hara et al. (2017: fig. S3) sample Ophiuroidea sp_IE.2009.1713 (= Ophiophrixus_confinis) and additional unpublished exon-capture data on samples Ophiobyrsa_rudis_F222711 and Ophiosmilax_sp_IE.2207.6967. All-sites PLRS/RAxML tree with node support and age confidence intervals (coloured bars). Node support shows all-sites RAxML BS followed by the proportion of the data subset trees in agreement. For all other nodes support was 100/1. The root was fixed according to O'Hara et al. (2014) at $270 \mathrm{Ma}$. 
The terms oral papillae, apical papillae, infradental papillae, tooth papillae and teeth (Fig. 2B$\mathrm{C}, \mathrm{G})$ cause considerable confusion, as they have been applied to non-homologous structures across the diversity of Ophiuroidea. We have studied the dental plates and jaws of numerous species and propose here a clear way to distinguish between these structures (Martynov 2010b; Thuy \& Stöhr 2016; Stöhr \& Martynov 2016). Oral papillae at the ventral or ventrolateral edge of the dental plate lack corresponding sockets on the dental plate. Ontogenetically, these develop laterally at the dental plate and move below the teeth (= in infradental position) (Hendler 1978; Stöhr 2005) to varying degree, depending on the species. Thus defined, infradental papillae are found in more taxa than previously assumed (see diagnoses below). In contrast, teeth and so called tooth papillae sit on sockets on the dental plate (Fig. 2H). Consequently, the term apical papilla, commonly used in the literature, usually refers to a ventral tooth, whereas the infradental papillae are oral papillae. Tooth papillae should better be viewed as teeth, since they cannot unambiguously be distinguished from apical tooth clusters, and both
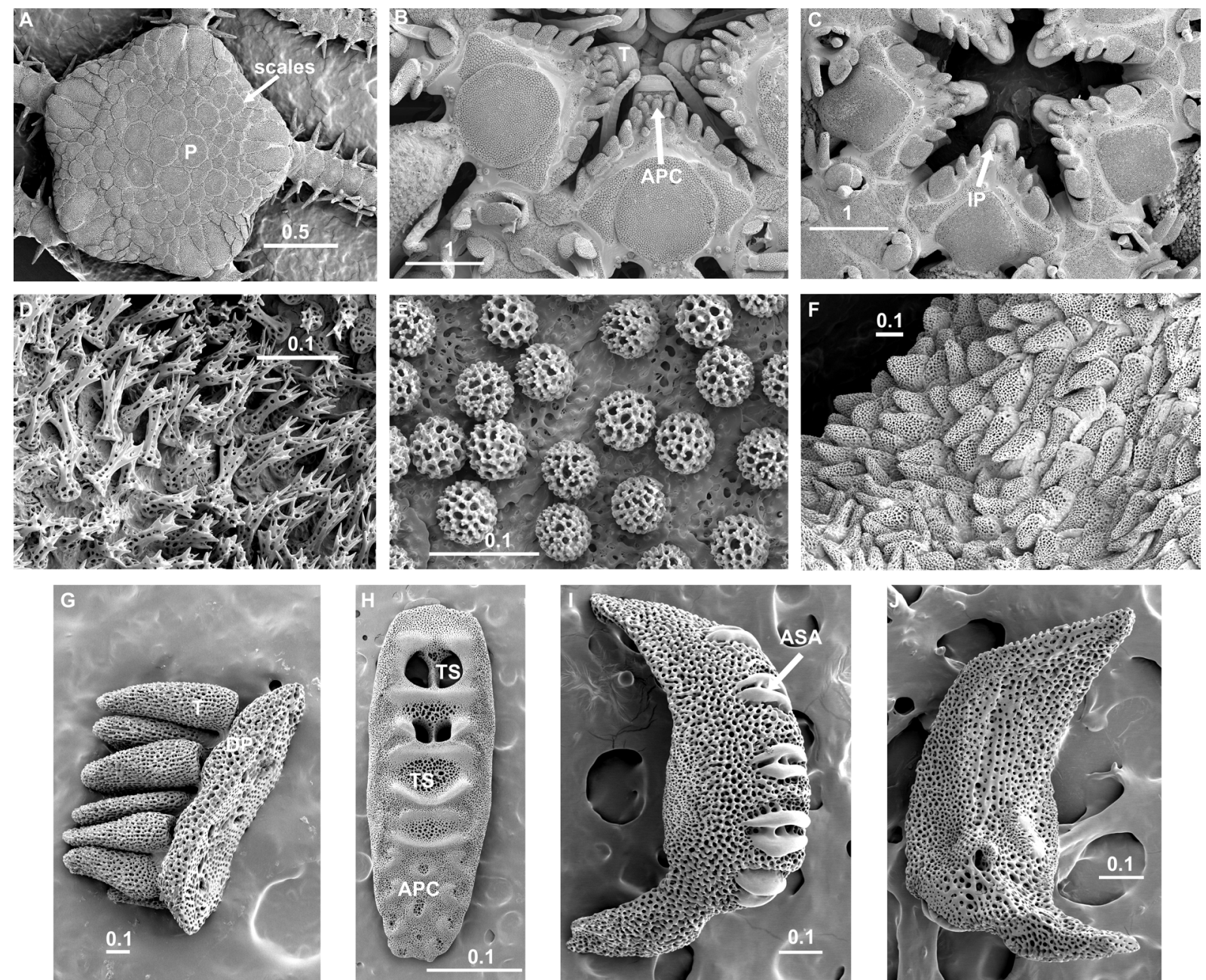

Fig. 2. Examples of skeletal structures of brittlestars. A. Dorsal disc with scales and plates in Amphiura Forbes, 1843 (P). B. Oral frame with teeth (T) and apical tooth cluster (APC) in Ophiocoma L. Agassiz, 1836. C. Oral frame with infradental oral papillae (IP) in Ophioplax Lyman, 1875. D. Disc spines in Ophiacantha Müller \& Troschel, 1842. E. Disc granules in Ophiocoma L. Agassiz, 1836. F. Disc tubercles in Acrocnida Gislén, 1926. G. Dental plate (DP) in Ophiura Lamarck, 1801, with teeth attached. H. Dental plate with sockets for regular teeth (TS) and for apical tooth cluster (APC) in Ophiocoma L. Agassiz, 1836. I-J. Lateral arm plate in Amphiura Forbes, 1843. I. External view with arm spine articulations (ASA). J. Internal view. Scale bars in millimetres. 
tooth papillae and tooth clusters have evolved multiple times. In addition, both teeth and tooth papillae articulate to the dental plate on sockets, whereas infradental oral papillae have no sockets. Instead, dental plates with infradentals are usually laterally tapered at their ventral end.

Disc granules and disc spines (Fig. 2D-F) refer to different shapes of the same structure, and there are numerous variations of intermediate forms between granule and spine, all are articulated to disc scales and/or plates, sometimes extending onto the arms. Tubercles are outgrowths of ossicles, not articulated. External, epidermal or dermal ossicles are terms that have been used for granule- or scale-like ossicles in the epidermis covering the disc and arms of Euryalida (Okanishi et al. 2011a, 2013), giving the impression that these are novel structures, found only in this order. There is however no evidence against a homology of granules and scales across all Ophiuroidea and the same terminology should be used until found otherwise.

The arm spine articulations (Fig. 2I) have been treated in detail by Martynov (2010a, 2010b), who demonstrated their strong phylogenetic signal. They consist of a large variety of lobes, ridges and knobs, bordering usually two, sometimes one, opening(s) for muscle and nerve, passing through to the spine. Thuy \& Stöhr (2011) studied the lateral arm plates (Fig. 2I-J) and later identified a total of 42 characters on these alone (Thuy \& Stöhr 2016), phylogenetically important on various taxonomic levels.

Arm vertebrae are subject to ecological adaptation and show convergent evolution. Thus, hourglassshaped vertebral articulations are found in several taxa with epizoic life style, whereas their relatives have zygospondylous articulations. This character cannot therefore be used on its own but it is helpful in combination with other characters or to differentiate closely related groups. In some Euryalidae, the ventral vertebral furrow, in which the radial water vascular canal and radial nerve are placed, is closed by a structure known as "oral bridge" (Mortensen 1933; Okanishi et al. 2011b).

\title{
Results
}

\section{New classification scheme of Recent Ophiuroidea (family and higher ranks)}

\author{
Phylum Echinodermata Bruguière, 1791 \\ Subphylum Asterozoa von Zittel, 1895 \\ Class Ophiuroidea Gray, 1840 \\ Subclass Myophiuroidea Matsumoto, 1915 \\ Infraclass Metophiurida Matsumoto, 1913 (crown-group of Ophiuroidea) \\ Superorder Euryophiurida O’Hara et al., 2017 \\ Order Euryalida Lamarck, 1816
}

\section{Diagnosis}

Arm spine articulations with muscle and nerve openings well separated. Arm spines ventral only. Lateral arm plates devoid of ornamentation. Vertebrae with hourglass-shaped articulations.

Family Asteronychidae Ljungman, 1867

\section{Type genus}

Asteronyx Müller \& Troschel, 1842 (type species: A. loveni Müller \& Troschel, 1842).

\section{Other genera}

Astrodia Verrill, 1899b, Astronebris Downey, 1967, Ophioschiza H.L. Clark, 1911. 


\section{Diagnosis}

Dorsal disc with thickened skin, few or no scales, radial shields bar-like, almost meeting in disc centre. Long, tapering arms, covered by thickened skin, lacking dorsal plates. Multiple columns of spiniform teeth, dental plate entire. Arms not branching. All vertebrae without oral bridge. Gonads restricted to disc. Arm spine articulation as slightly tumid regular stereom with large oval or round opening.

Family Euryalidae Gray, 1840

\section{Type genus}

Euryale Lamarck, 1816 (type species: E. aspera Lamarck, 1816).

\section{Other genera}

Asteromorpha Lütken, 1869, Asteroschema Örstedt \& Lütken, 1856, Asterostegus Mortensen, 1933a, Astrobrachion Döderlein, 1927, Astroceras Lyman, 1879, Astrocharis Koehler, 1904, Ophiocreas Lyman, 1869, Squamophis Okanishi et al. 2011, Sthenocephalus Koehler, 1898, Trichaster Agassiz, 1836.

\section{Diagnosis}

Dorsal disc with thickened skin and embedded external ossicles. Single column of teeth, dental plate fragmented. Arms branching in Euryale, Trichaster and Sthenocephalus. Distal vertebrae with oral bridge in Asteromorpha, Asterostegus, Astrobrachion, Astroceras, Euryale, Sthenocephalus and Trichaster (Okanishi et al. 2011b). Gonads may extend into the arms. Arm spine articulation with large muscle opening separated from the nerve opening by a large, swollen ridge.

Family Gorgonocephalidae Ljungman, 1867

Astrochelidae Verrill, 1899a: 79.

\section{Type genus}

Gorgonocephalus Leach, 1815 (type species: G. caputmedusae (Linnaeus, 1758)).

\section{Other genera}

Asteroporpa Örstedt \& Lütken, 1856, Astracme Döderlein, 1927, Astroboa Döderlein, 1911, Astrocaneum Döderlein, 1911, Astrochalcis Koehler, 1905, Astrochele Verrill, 1878, Astrochlamys Koehler, 1912, Astrocladus Verrill, 1899b, Astroclon Lyman, 1879, Astrocnida Lyman, 1872, Astrocrius Döderlein, 1927, Astrocyclus Döderlein, 1911, Astrodendrum Döderlein, 1911, Astrodictyum Döderlein, 1927, Astroglymma Döderlein, 1927, Astrogomphus Lyman, 1869, Astrogordius Döderlein, 1911, Astrohamma Döderlein, 1930, Astrohelix Döderlein, 1930, Astroniwa McKnight, 2000, Astrophyton Fleming, 1828, Astroplegma Döderlein, 1927, Astrosierra Baker, 1980, Astrospartus Döderlein, 1911, Astrothamnus Matsumoto, 1915, Astrothorax Döderlein, 1911, Astrothrombus H.L. Clark, 1909a, Astrotoma Lyman, 1875, Astrozona Döderlein, 1930, Conocladus H.L. Clark, 1909b, Ophiocrene Bell, 1894, Ophiozeta Koehler, 1930, Schizostella A.H. Clark, 1952.

\section{Diagnosis}

Dorsal disc and arms with scales and plates, which bear thorny granules or spines. Girdles of small hyaline hooks on the arms. Arms branching or simple. All vertebrae without oral bridge. Gonads restricted to disc. Multiple teeth in irregular columns, dental plate entire. Arm spine articulation with slit-shaped muscle opening proximally bordered by vertical ridge, small nerve opening at a distance. 
Order Ophiurida Müller \& Troschel, 1840, restricted sensu O’Hara et al. (2017)

\section{Diagnosis}

Arms never branching. Spine articulation with muscle opening generally surrounded by ridges and/or knobs and separated from nerve opening by vertical ridge, lateral arm plates generally with external ornamentation (tubercles, striation, spurs). Strong influence of paedomorphosis (Stöhr \& Martynov 2016).

Suborder Ophiomusina O’Hara et al., 2017

\section{Diagnosis}

Dental plate entire, sockets shallow, single row of teeth. Tentacle openings minute within-plate perforations of the lateral arm plate, except on proximal arm joints. Lateral arm plates conspicuously thick and meeting dorsally and ventrally. Genital papillae restricted to ventral side. Second tentacle pore concealed inside mouth slit.

Family Ophiosphalmidae fam. nov.

urn:Isid:zoobank.org:act:67BE8BBA-D959-40E4-9E02-73A9F483A18E

\section{Type genus}

Ophiosphalma H.L. Clark, 1941 (type species: O. planum (Lyman, 1878b) = O. armigerum (Lyman, 1878a)).

\section{Other genera}

Ophiolipus Lyman, 1878b, Ophiomusium Lyman, 1869 (only species O. eburneum Lyman, 1869).

\section{Diagnosis}

Numerous disc scales, small primary plates. Dorsal and ventral arm plates present along most of the arm. Lateral arm plate with a finely meshed proximal band that lacks spurs. Longer genital slits than Ophiomusa. Three (rarely 2-5) visible proximal pairs of tentacle pores. Frequently with small disc spines distal to the genital slit around the disc margin. In our molecular analysis, the genus Ophiolipus (lacking disc plates) is polyphyletic.

Family Ophiomusaidae fam. nov. urn:lsid:zoobank.org:act:08A62334-062A-4968-9548-4C3EFCE61712

\section{Type genus}

Ophiomusa Hertz, 1927 (type species: O. lymani (Wyville-Thomson, 1873)).

\section{Diagnosis}

Disc scales few, primary plates obvious, radial shields enlarged. Ventral arm plates, and in some species also dorsal arm plates, present on few proximal arm joints only. Lateral arm plates with numerous spurs along proximal edge. Extremely short genital slits, rarely as long as first arm joint. Two visible proximal pairs of tentacle pores. 


\section{Remarks}

Hertz (1927) included 11 species in the genus Ophiomusa - canaliculata (H.L. Clark, 1917), facunda (Koehler, 1922a), fallax (Koehler, 1904), luetkeni (Lyman, 1878), lunaris (Lyman, 1878), lymani, muta Hertz, 1927 (as subspecies of facunda), relicta (Koehler, 1904), scalare (Lyman, 1878), trychna (H.L. Clark, 1911) and ultima Hertz, 1927 - many of them with a more simplified skeleton than the type species O. lymani (Baker 2016). The type species of Ophiomusium, O. eburneum, is genetically and morphologically related to Ophiosphalma and not to the other described species of Ophiomusium. It has 2-3 pairs of visible tentacle pores and persistent ventral and dorsal arm plates, and rounded, almost bulging lateral arm plates. The remaining species of Ophiomusium form a distinct family-level clade with typically 2 (rarely 0 or 1) pairs of visible tentacle pores. Consequently, we transfer these remaining species to the only available genus name, Ophiomusa Hertz, 1927, which until now has been treated as a synonym of Ophiomusium. A future molecular and morphological revision of the Ophiomusaidae fam. nov. may reveal several monophyletic clades at genus level.

Suborder Ophiurina Müller \& Troschel, 1840 sensu O’Hara et al. 2017

\section{Diagnosis}

Genital papillae on adradial genital plate form an arm comb (secondarily lost in Astrophiuridae) at the distal end of the plate. Cluster of teeth on ventral part of dental plate. Lateral arm plates generally much more fragile than in Ophiomusina. Many strongly paedomorphic taxa in which arm combs and oral tooth clusters may be reduced or absent. Second tentacle pore outside of mouth slit or opening into it but never concealed.

Family Astrophiuridae Sladen, 1879a

\section{Type genus}

Astrophiura Sladen, 1879a (Type species: A. permira Sladen, 1879b).

\section{Other genera}

Ophiomisidium Koehler, 1914, Ophiophycis Koehler, 1901.

\section{Diagnosis}

Dorsal disc composed of very obvious primary plates, interradial plates and radial shields, few or no disc scales. Single apical ventralmost tooth. No genital papillae, no arm combs. Strongly paedomorphic genera with reduced skeleton; Astrophiura with highly modified lateral arm plates on proximal joints. Arm spine articulation as simple muscle opening, bordered by thickened stereom, nerve opening reduced.

Family Ophiuridae Müller \& Troschel, 1840, restricted sensu O’Hara et al. (2017)

\section{Type genus}

Ophiura Lamarck, 1801 (type species: O. ophiura (Linneaus, 1758)).

\section{Other genera}

Ophiocrossota H.L. Clark, 1928, Ophiocten Lütken, 1855, Ophioctenella Tyler et al., 1995, Ophionotus Bell, 1902.

\section{Diagnosis}

Flat disc, usually fully scaled but naked in some species. Genital papillae and arm combs present, although combs in Ophionotus reduced. Dental plate entire, sockets small round holes, not perforating, 
with low borders; single, offset column, ventral cluster. Lateral arm plates commonly divided in two halves by central, distalwards-pointing tentacle notch. Arm spine articulation with large, irregularly round muscle opening on an elevation, nerve opening at base of elevation.

\section{Remarks}

Ophiura may be polyphyletic and needs to be revised (e.g., O. robusta (Ayres, 1852) has hooked spines on the distal arm, a character of Ophiopyrgidae Perrier, 1893). The subgenus Ophiuroglypha Hertz, 1927 is herein raised to genus-rank and referred to the Ophiopyrgidae. The available genus name Glaciacantha Fell, 1961b is used herein to contain two Southern Ocean species of Ophiocten (dubium Koehler, 1901 and doederleini Hertz, 1927) with raised disc plates and hooked distal arm spines, and also transferred to the Ophiopyrgidae.

Family Ophiopyrgidae Perrier, 1893

\section{Type genus}

Ophiopyrgus Lyman, 1878a (type species: O. wyvillethomsoni Lyman, 1878a).

\section{Other genera}

Amphiophiura Matsumoto, 1915, Aspidophiura Matsumoto, 1915, Dictenophiura H.L. Clark, 1923, Euvondrea Fell, 1961a, Glaciacantha Fell, 1961b, Gymnophiura Lütken \& Mortensen, 1899, Ophiogona Studer, 1876, Ophiomages Koehler, 1923, Ophioperla Koehler, 1912, Ophiopleura Danielssen \& Koren, 1877, Ophioplinthus Lyman, 1878a, Ophiosparte Koehler, 1922b, Ophiosteira Bell, 1902, Ophiuroglypha Hertz, 1927, Spinophiura Stöhr \& Segonzac, 2006, Stegophiura Matsumoto, 1915.

\section{Diagnosis}

High disc with few to many scales, primary plates obvious (but Ophiosparte with thickened skin covering the disc scales and plates; Ophiopleura with scales embedded in thickened skin). Arm combs present but often not as well expressed as in Ophiuridae. Lateral arm plates generally with ventro-distalwardspointing tentacle notch, often with within-plate tentacle perforation in median to distal arm portions. Distal arm spines often hooked. Arm spine articulation oval to slit-shaped with lower lip, nerve opening at a distance, in paedomorphic taxa such as Ophiopyrgus weakly expressed as slightly larger pore in the stereom of the lateral arm plate.

\section{Remarks}

Ophiopyrgus is a paedomorphic species with reduced morphology. It is therefore not ideal as typical genus for the characterization of a family but the name Ophiopyrgidae has priority. The expression of typical characters varies greatly among the included genera, many specializations occur.

\section{Ophiurida incertae sedis}

Abyssura Belyaev \& Litvinova, 1976, Anophiura H.L. Clark, 1939, Anthophiura H.L Clark, 1911, Bathylepta Belyaev \& Litvinova, 1972, Haplophiura Matsumoto, 1915, Ophiochalcis Koehler, 1930, Ophiochrysis Koehler, 1904, Ophiochytra Lyman, 1880, Ophiolebella Mortensen, 1936, Ophiomaria A.H. Clark, 1916, Ophiomastus Lyman, 1878a, Ophiopenia H.L. Clark, 1911, Ophiophyllum Lyman, 1878a, Ophiotjalfa Mortensen, 1913, Ophiotrochus Lyman, 1878a, Ophiuraster H.L. Clark, 1939, Perlophiura Belyaev \& Litvinova, 1972, Uriopha Paterson, 1980. (Most of these fit morphologically with Ophiopyrgidae, but in the light of their paedomorphic morphology and lack of genetic data, we refrain from placing them at this time). 
Superorder Ophintegrida O’Hara et al., 2017

Order Ophioscolecida O'Hara et al., 2017

\section{Remarks}

The radial shields are small and concealed by disc scales or absent in most of the included genera, which may suggest reduction of radial shields as synapomorphy of Ophioscolecida.

Family Ophiohelidae Perrier, 1893

Ophiomycetidae Verrill, 1899b: 359 (see Thuy \& Meyer 2013; Parameswaran et al. 2016).

\section{Type genus}

Ophiohelus Lyman, 1880 (type species: O. umbella Lyman, 1880).

\section{Other genera}

Ophiomyces Lyman, 1869, Ophiothauma H.L. Clark, 1938, Ophiotholia Lyman, 1880.

\section{Diagnosis}

Disc fully scaled but radial shields absent, giving the disc a sac-like shape. Jaws (oral plates) covered by numerous flat papillae, except in Ophiothauma. Large flat teeth. Arm spine articulations separated from distal edge by a fragile ledge with a distalwards pointing ventral extension. Articulation with nearly vertical dorsal and ventral lobes, connected at their proximal ends, opening into a wide y- or horseshoeshape, bordering a single muscle/nerve opening, dorsal lobe larger and bent. Lateral arm plates generally with irregular, smooth vertical striation. Conspicuous parasol-shaped arm spines in Ophiohelus and Ophiotholia. Ventral arm plates often with sockets for tentacle scales.

Family Ophioscolecidae Lütken, 1869 (emended, paraphyletic assemblage, see Fig. 2)

\section{Type genus}

Ophioscolex Müller \& Troschel, 1842 (type species: O. glacialis Müller \& Troschel, 1842).

\section{Other genera}

Ophiocymbium Lyman, 1880, Ophiogeron Lyman, 1878a, Ophiohyalus Matsumoto, 1915, Ophiohymen H.L. Clark, 1911, Ophioleptoplax H.L. Clark, 1911, Ophiologimus H.L. Clark, 1911, Ophiolycus Mortensen, 1933a, Ophiophrura H.L. Clark, 1911, Ophioplexa Martynov, 2010, Ophioprium H.L. Clark, 1915a, Ophiorupta Martynov, 2010, Ophiosyzygus H.L. Clark, 1911, Ophiuroconis Matsumoto, 1915.

\section{Diagnosis}

Dorsal disc and arms with thickened skin, thin glassy disc scales, reduced in number or absent in some genera (Ophioscolex), mostly naked but scattered smooth disc spines or dense granules occur in some species. Spiniform teeth, forming apical clusters in some genera, spiniform oral papillae. Paired ventralmost teeth, dental plate entire, round sockets, not penetrating. Arm spine articulations adjacent to distal edge of lateral plate, as single opening for both muscle and nerve, with a horseshoe-shaped border in some genera (Ophioscolex, Ophiogeron), as separate nerve and muscle openings bordered by a larger dorsal and smaller ventral lobe in others (Ophiolycus). 
Order Ophiacanthida O’Hara et al., 2017

\section{Diagnosis}

Radial shields often with distal portion exposed (or only proximal tip concealed). Arm spine articulations with bent dorsal and ventral lobes merged at their proximal tips, and generally with sigmoidal fold.

Suborder Ophiacanthina O’Hara et al., 2017

\section{Diagnosis}

Abradial genital plate without conspicuous ridges or perforations. Arm spines smooth or with lateral thorns. Dorsalward increase in size of spine articulations. Lateral arm plates commonly with constriction leading to raised distal portion. Generally row of small perforations (putatively associated with arm spine innervation) in shallow vertical furrow on inner side of lateral arm plates.

Family Ophiobyrsidae Matsumoto, 1915 stat. nov. (raised to family-rank)

\section{Type genus}

Ophiobyrsa Lyman, 1878a (type species: O. rudis Lyman, 1878a).

\section{Other genera}

Ophiobyrsella Verrill, 1899b, Ophiosmilax Matsumoto, 1915, Ophiophrixus H.L. Clark, 1911.

\section{Diagnosis}

Disc and arms covered by thickened skin bearing pointed spines, large radial shields. Vertebrae with hourglass-shaped articulation. Multiple columns of spiniform teeth on round, knob-like sockets, not perforating the dental plate. Ventral tooth cluster. Spine articulation asymmetrical with large, swollen dorsal lobe and small, indistinct ventral lobe. No sigmoidal fold. Lateral arm plates without ornamentation.

\section{Remarks}

New molecular data indicates that the genera Ophiobyrsa, Ophiophrixus and Ophiosmilax form a clade that is sister to all remaining ophiacanthid families. Consequently, the former subfamily Ophiobyrsinae Matsumoto, 1915 is raised to family-level rank.

Family Ophiocamacidae fam. nov. urn:1sid:zoobank.org:act:30C91042-C4FE-4373-9C62-B0D906F16541

\section{Type genus}

Ophiocamax Lyman, 1878a (type species: O. vitrea Lyman, 1878a).

\section{Diagnosis}

Dorsal disc with spines with multipointed crowns. Ventral cluster of spiniform teeth, dental plate entire, sockets small, not penetrating. Numerous spiniform oral papillae clustered at lateral jaw edges. Vertebral articulation hourglass-shaped. Arm spines thin, round in cross section, with lateral thorns. Pointed thornlike tubercles on dorsal, ventral and lateral arm plates. Proximal tentacle pores with multiple elongated erect scales, forming a sheath through which the foot emerges, distally a single thorny scale, penetrated by foot $(O$. vitrea). Arm spine articulations conspicuously large muscle opening encompassed by rather thin dorsal and ventral lobes forming an irregular circle. Row of spine articulations on midline of raised distal portion of lateral arm plate. Second or third dorsalmost spine articulation often much larger than others. 
Family Ophiotomidae Paterson, 1985 stat. nov.

Ophiotretidae O’Hara et al., 2017: 421, figs 1-2 (nomen nudum).

\section{Type genus}

Ophiotoma Lyman, 1883 (type species: O. coriacea Lyman, 1883).

\section{Other genera}

Ophiocomina Koehler in Mortensen, 1920, Ophiocopa Lyman, 1883, Ophiomitra Lyman, 1869, Ophiopristis Verrill, 1899a, Ophiotreta Verrill, 1899a.

\section{Diagnosis}

Dorsal disc with granules or long, thorny spines. Abradial genital plate with concave adradio-distal tip. Arm spines flattened, laterally serrated. Dental plate fragmented (Ophiotreta, Ophiocopa) or entire (Ophiocomina, Ophiotoma), sockets shallow. Ventral clusters of short, papilliform teeth in Ophiotreta and Ophiocomina. Arm spine articulation lobes with small perforations or imperforate. Ridge on the inner side of the lateral arm plates with two kinks and a ventro-proximalwards pointing projection associated with the dorsal kink. This family was mistakenly named Ophiotretidae in O'Hara et al. (2017).

\section{Remarks}

The species Ophiocomina australis H.L. Clark, 1928 is a Clarkcoma species (Naughton et al. 2014; O'Hara et al. 2017), which leaves Ophiocomina monotypic. Ophiotoma is polyphyletic (O'Hara et al. 2017).

Family Ophiopteridae fam. nov. urn:1sid:zoobank.org:act:28D7ECF8-2D03-4F4B-874B-8D998E39561D

\section{Type genus}

Ophiopteris E.A. Smith, 1877 (type species: O. antipodum E.A. Smith, 1877).

\section{Diagnosis}

Dorsal disc with dense cover of low granules, obscuring scales and plates. Ventral disc with short spines. Several small, conical lateral oral papillae. Long, smooth, cylindrical, erect arm spines, the two dorsalmost small, scale-like. Several columns of small papilliform teeth all over dental plate, no regular teeth. Dental plate entire. Tooth sockets on dental plate without foramina and teeth without glassy tips (Devaney 1970). Arm spine articulation lobes merged, with proximal and dorsal swellings, nerve and muscle openings widely separated.

Family Clarkcomidae fam. nov.

urn:1sid:zoobank.org:act:3A1F5F7F-3A02-406F-8D81-D6CF66472181

\section{Type genus}

Clarkcoma Devaney, 1970 (type species: C. canaliculata (Lütken, 1869)).

Diagnosis (Devaney 1970)

Dorsal disc with low rounded granules, obscuring scales and plates. Blunt, thin, compressed, minutely serrated arm spines. Dental plate entire. Cluster of papilliform teeth on ventral half, regular teeth on 
dorsal half. Teeth with glassy tips. Tooth sockets on dental plate with thickened lobes, dorsal ones as penetrating, large foramina.

Family Ophiacanthidae Ljungman, 1867

\section{Synonyms}

Ophiochondrinae Verrill, 1885: 355.

Ophioplinthacinae Paterson, 1985: 61.

Ophiocanopidae Mortensen, 1932: 8.

\section{Type genus}

Ophiacantha Müller \& Troschel, 1842 (type species: O. bidentata (Bruzelius, 1805)).

\section{Other genera}

Ophialcaea Verrill, 1899a, Ophientrema Verrill, 1899b, Ophiocanops Koehler, 1922a, Ophiochondrus Lyman, 1869, Ophiohamus O'Hara \& Stöhr, 2006, Ophiolebes Lyman, 1878a, Ophiolimna Verrill, 1899a, Ophiomitrella Verrill, 1899a, Ophiomoeris Koehler, 1904, 'Ophiophthalmus' Matsumoto, 1917, Ophioplinthaca Verrill, 1899b, Ophioripa Koehler, 1922a, Ophiosemnotes Matsumoto, 1917, Ophiurothamnus Matsumoto, 1917.

\section{Diagnosis}

Dorsal disc fully scaled, with thorny spines or granules, or with thickened skin. No tooth clusters. Dental plate entire with single column of wide sockets with low dorsal and ventral border, not penetrating. Arm spine articulations bordered by raised, dorsoventrally striated ridge. Ventral portion of lateral arm plates (the portion below the row of spine articulations) small and not protruding ventro-proximalwards. Ridge on inner side of lateral arm plates with two kinks and a dorsal tip with a ventro-proximalwards pointing projection.

\section{Remarks}

The genera Ophiacantha, Ophiomitrella and Ophiolebes are polyphyletic and require revision.

Suborder Ophiodermatina Ljungman, 1867

\section{Diagnosis}

Abradial edge of radial shield excavated. Abradial genital plate with a longitudinal groove and a large perforation. Arm spines commonly with minute scale-like tubercles. Dorsal arm plates with spur on the proximal edge.

Superfamily Ophiodermatoidea Ljungman, 1867

\section{Diagnosis}

Arm spine articulations inserted in distal edge of lateral plate. Ventral arm plates commonly with spur on proximal edge.

Family Ophiodermatidae Ljungman, 1867

\section{Type genus}

Ophioderma Müller \& Troschel, 1840 (type species: O. longicauda (Bruzelius, 1805)). 


\section{Other genera}

Bathypectinura H.L. Clark, 1909b, Cryptopelta H.L. Clark, 1909b, Diopederma H.L. Clark, 1913, Ophiarachnella Ljungman, 1872, Ophiochasma Grube, 1868, Ophiocormus H.L. Clark, 1915a, Ophiocryptus H.L. Clark, 1915b, Ophiocypris Koehler, 1930, Ophiomidas Koehler, 1904, Ophiopsammus Lütken, 1869.

\section{Diagnosis}

Dorsal disc covered with granules. Dental plate fragmented, with finely meshed stereom, tooth sockets as broadly oval, not penetrating depressions with swollen borders, small tooth cluster on ventral end. Lateral arm plate with two proximal spurs, visible on external and internal surface. Arm spine articulation with weak sigmoidal fold, sunken in notches of distal plate edge.

\section{Remarks}

Ophiarachnella is polyphyletic and requires revision. The type species O. gorgonia Müller \& Troschel, 1842, however, is a confirmed ophiodermatid (O'Hara et al. 2017).

Family Ophiopezidae fam. nov. urn:1sid:zoobank.org:act:5CB2AA19-60FA-4483-A659-998AF13B3E55

\section{Type genus}

Ophiopeza Peters, 1851 (type species: O. fallax Peters, 1851).

\section{Other genera}

Ophiochaeta Lütken, 1869.

\section{Diagnosis}

Dorsal disc covered with granules (Ophiopeza) or needle-like spines (Ophiochaeta). Dental plate entire, with coarsely porous stereom, tooth sockets as small, not penetrating holes with indistinct borders, on the ventral end a pair of sockets. Arm spine articulation with swollen dorsal lobe and thin ventral lobe, well defined sigmoidal fold. Lateral arm plates with conspicuous ornamentation (tubercles of variable size in Ophiopeza).

Family Ophiomyxidae Ljungman, 1867

\section{Synonym}

Ophiarachninae Matsumoto, 1915: 83.

\section{Type genus}

Ophiomyxa Müller \& Troschel, 1842 (type species: O. pentagona (Lamarck, 1816)).

\section{Other genera}

Neoplax Bell, 1884, Ophiarachna Müller \& Troschel, 1842, Ophioconis Lütken, 1869, Ophiostiba Matsumoto, 1915, Ophiurochaeta Matsumoto, 1915.

\section{Diagnosis}

Dorsal disc covered with granules or naked thickened skin, scales reduced in Ophiomyxa. Dental plate fragmented, sockets with flat borders, not penetrating. Ophiarachna with small ventral tooth cluster. 
Hyaline, large, flat, serrated teeth in Ophiomyxa and Ophioconis. Lateral arm plates reminiscent of an upside-down Y-shape. Arm spine articulation without sigmoidal fold. Arm spine articulations generally larger than in Ophiodermatidae and Ophiopezidae fam. nov. and in shallower notches or on same level as plate stereom (Ophiomyxa), of rounded shape with smooth stereom.

\section{Remarks}

Ophiomyxa has a specialized morphology with many reductions of the skeleton and is thus not typical for this family but the name has priority. Ophiocanopidae Mortensen, 1932 was synonymized with Ophiomyxidae by Stöhr et al. (2008) but Ophiocanops is now a member of Ophiacanthidae.

Superfamily Ophiocomoidea Ljungman, 1867

\section{Diagnosis}

As for Ophiocomidae Ljungman, 1867 (see below).

Family Ophiocomidae Ljungman, 1867

\section{Type genus}

Ophiocoma L. Agassiz, 1836 (type species: O. echinata (Lamarck, 1816)).

\section{Other genera}

Breviturma Stöhr et al. 2013 stat. nov., Ophiarthrum Peters, 1851, Ophiocomella A.H. Clark, 1939, Ophiomastix Müller \& Troschel, 1842.

\section{Diagnosis}

Dorsal disc with granules, smooth spines or naked thickened skin. Oral plate with large abradial flange with horizontal grooves. Dental plate entire, dorsalmost sockets as large penetrating holes, with vertical septum, large cluster of teeth ventrally. Teeth with hyaline tip. Spine articulations very large, with dorsalward increase in size, freestanding on raised distal portion of lateral arm plates. Lateral arm plates with very small proximal spurs if any. Inner side of lateral arm plates with single, large perforation (putatively for bundled arm spine nerves).

\section{Remarks}

We raise Breviturma from subgeneric to generic level. Ophiocoma is polyphyletic and requires revision.

\section{Ophiacanthida incertae sedis}

Microphiura Mortensen, 1910, Ophioblenna Lütken, 1859, Ophiobrachion Lyman, 1883, Ophiacanthella Verrill, 1899a, Ophiochondrella Verrill, 1899b, Ophioclastus Murakami, 1943, Ophiodaces Koehler, 1922b, Ophiodelos Koehler, 1930, Ophiodictys Koehler, 1922a, Ophiodyscrita H.L. Clark, 1938, Ophiogema Koehler, 1922a, Ophiolamina Stöhr \& Segonzac, 2006, Ophiomedea Koehler, 1906, Ophiomora Koehler, 1907, Ophioncus Ives, 1889, Ophiopaepale Ljungman, 1872, Ophioparva Guille, 1982, Ophiosciasma Lyman, 1878a, Ophiostyracium H.L. Clark, 1911, Pectinura Forbes, 1843, Ophiambix Lyman, 1880. (Some of the above genera were previously placed in Ophiomyxidae. They may belong in Ophioscolecidae instead but more data are needed.) 
Order Ophioleucida O'Hara et al., 2017

\section{Diagnosis}

Dorsal disc with granules. Radial shields with distal adradial portion exposed. Abradial genital plate with concave adradio-distal tip. Dorsal arm plates rectangular to trapezoid with straight edges. Arm spine articulations irregularly rhombic, framing large, dorsoventrally elongated muscle opening, small nerve opening ventral to articulation. Lateral arm plates fragile. Arm spine articulations commonly separated from distal plate edge by a ledge. Ventro-distal edge of lateral arm plates protruding ventralwards.

Family Ophiernidae fam. nov.

urn:1sid:zoobank.org:act:4FF0D5F3-DF26-4CA0-A6FD-F4C6B6696C1A

\section{Type genus}

Ophiernus Lyman, 1878a (type species: O. vallincola Lyman, 1878a).

\section{Diagnosis}

Lateral arm plates without vertical striations, but with horizontally striated proximal band (under adjacent plate). Bristle-shaped accessory arm spines. Narrow, broad, imperforate tooth sockets with flat borders. Vertebrae with radiating rib-like structures on distal muscle flanges. Lateral arm plates with several rib-like spurs on external proximal/internal distal band (where adjacent plates overlap). Arm spine articulations with weak lobes.

Family Ophioleucidae Matsumoto, 1915 (restricted)

\section{Type genus}

Ophioleuce Koehler, 1904 (type species: O. seminudum Koehler, 1904).

\section{Other genera}

Ophiopallas Koehler, 1904, Ophiopyren Lyman, 1878a, Ophiostriatus Madsen, 1983.

\section{Diagnosis}

Tooth sockets as round holes with indistinct borders. Vertebrae with smooth distal muscle flanges. No accessory arm spines. Lateral arm plates with vertical striations, single spur on dorsal part of external proximal/internal distal edge (where adjacent plates overlap). Arm spine articulations with swollen lobes.

Order Amphilepidida O'Hara et al., 2017

\section{Diagnosis}

Ventral end of dental plate laterally tapered. Infradental papillae. Abradial genital plate with concave adradio-distal tip. Dorsal and ventral lobes of arm spine articulations parallel (except in Ophiotrichidae).

Suborder Ophionereidina O'Hara et al., 2017

Superfamily Ophiolepidoidea Ljungman, 1867

\section{Diagnosis}

Disc with stout plates, few or no stout scales, neither granules nor spines. Primary plates usually distinct. Spine articulations small and generally sunken in notches of distal plate edge. 
Family Ophiolepididae Ljungman, 1867 (restricted)

\section{Type genus}

Ophiolepis Müller \& Troschel, 1840 (type species: O. superba H.L. Clark, 1915).

\section{Other genera}

Ophioteichus H.L. Clark, 1938, Ophiotypa Koehler, 1897.

\section{Diagnosis}

Accessory dorsal and ventral arm plates. Tooth sockets large, round to oval, with low, indistinct borders, deep but not penetrating. Lateral arm plates with single spur on ventral third of proximal half. Arm spine articulation with muscle and nerve openings of similar size. Finely porous stereom in all arm plates.

Family Hemieuryalidae Verrill, 1899

\section{Type genus}

Hemieuryale von Martens, 1867 (type species: H. pustulata von Martens, 1867).

\section{Other genera}

Actinozonella Stöhr, 2011, Astrogymnotes H.L. Clark, 1914, Ophioholcus H.L. Clark, 1915a, Ophioplus Verrill, 1899a, Ophiozonella Matsumoto, 1915, Ophiozonoida H.L. Clark, 1915a, Quironia A.H. Clark, 1934, Sigsbeia Lyman, 1878b, Ophioplocus Lyman, 1861.

\section{Diagnosis}

Dorsal disc with scales and plates or thickened skin, neither granules nor spines, but in some genera with tubercles. Strongly tuberculous stereom in all arm plates. No accessory arm plates. Arm spine articulation with single small opening (e.g., Hemieuryale) or separate muscle and nerve openings (e.g., Ophiozonella, Ophioplocus); articulations placed at an angle to each other. Tooth sockets shallow with indistinct borders in Hemieuryale but in Ophiozonella only ventral sockets like this, dorsal ones as large fenestrations with septum.

\section{Remarks}

Heteromorphic assemblage of genera with numerous reductions and specializations. The arm spine articulation with only two parallel ridges may be such a reduction, as the type species of Ophiozonella (O. longispina (H.L. Clark, 1908)) has the dorsal and ventral lobes proximally separated by a strong, irregularly denticulate ridge (or vertical series of merged knobs).

\section{Superfamily Ophionereidoidea Ljungman, 1867}

\section{Diagnosis}

Disc with numerous thin scales and few plates, partially covered by scales, indistinct primary plates, no granules or spines. Large spine articulations not sunken in depressions of distal plate edge. Lateral arm plates with a band of more finely meshed stereom only in the central part of the outer proximal edge. 
Family Amphilimnidae fam. nov.

urn:1sid:zoobank.org:act:304D30DE-9638-47B8-9AD4-CD1DB5AEDFD4

\section{Type genus}

Amphilimna Verrill, 1899a (type species: A. olivacea (Lyman, 1869)).

\section{Diagnosis}

Dorsal disc fully scaled, with rod-like smooth spines. Arm spines inside disc modified, large, flat scalelike. Long, spiniform tentacle scales. Abradial genital plate twisted. Tooth sockets round with indistinct borders, not perforating. Arm spine articulations with two smooth, parallel ridges, in the proximal space between them a short ridge (absent in some species). Inner side of lateral arm plates with two merged knobs instead of a ridge. Ventral arm plate with spur on the proximal edge.

\section{Family Ophionereididae Ljungman, 1867}

\section{Synonym}

Ophiochitonidae Matsumoto, 1915: 88 (see Smith, Paterson \& Lafay 1995).

\section{Type genus}

Ophionereis Lütken, 1859 (type species: O. reticulata (Say, 1825)).

\section{Other genera}

Ophiochiton Lyman, 1878a, Ophiodoris Koehler, 1904, Ophioneroides Cherbonnier \& Guille, 1978, Ophioplax Lyman, 1875.

\section{Diagnosis}

Granules along the genital slit, extending onto disc edge. Accessory dorsal arm plates (Ophionereis). Scale-like, flat, oval to round tentacle scales. Tooth sockets dorsally as large fenestrations with septum. Arm spine articulation horse-shoe shaped, with parallel dorsal and ventral lobes proximally separated by vertical row of knobs or merged by ribbed border, framing nerve and muscle openings of almost equal size. Internal of lateral arm plate with large pore close to the dorsal edge of the tentacle pore excavation, at the ventral tip of a large ridge along the inner proximal edge that bends ventro-distalwards. Vertebrae with distally protruding dorsal keel and proximal dorsal groove.

\section{Remarks}

Most characters apply only to Ophionereis and are modified or reduced in the other genera. The unifying characters are the lateral arm plate characteristics and the arm spine articulation.

Suborder Ophiopsilina Matsumoto, 1915

Superfamily Ophiopsiloidea Matsumoto, 1915

\section{Diagnosis}

As for Ophiopsilidae stat. nov.

Family Ophiopsilidae Matsumoto, 1915 stat. nov. (raised to family rank)

\section{Type genus}

Ophiopsila Forbes, 1843 (type species: O. aranea Forbes, 1843). 


\title{
Diagnosis
}

Dorsal disc fully scaled, neither spines nor granules. Extremely long, flat tentacle scales that cross on the mid-line of the ventral arm. Ventral tooth sockets shallow and indistinct, dorsalwards increasing in size and penetrating with septum. Oral plate (half-jaw) higher than long, with large dorsodistal muscle flange (similar to Amphiuridae). Arm spine articulations with two smooth, parallel, straight lobes, in the proximal space between them a short ridge (similar to Amphilimna). Inner side of lateral arm plates with two merged knobs instead of a ridge.

\section{Remarks}

The position of this family is variable in our molecular analyses with some trees supporting a sister relationship to the Ophionereidina and others to the Gnathophiurina (O'Hara et al. 2017). The morphological analysis supports a relationship within Gnathophiurina, close to Amphiuridea (Thuy \& Stöhr 2016).

\author{
Suborder Gnathophiurina Matsumoto, 1915 \\ Superfamily Amphiuroidea Ljungman, 1867
}

\section{Diagnosis}

Disc usually without spines, any occurring spines are not thorny. Arm spine articulations with parallel ridges.

Family Amphiuridae Ljungman, 1867

\section{Type genus}

Amphiura Forbes, 1843 (type species: A. chiajei Forbes, 1843).

\section{Other genera}

Acrocnida Gislén, 1926, Amphichondrius Nielsen, 1932, Amphicontus Hill, 1940, Amphigyptis Nielsen, 1932, Amphiodia Verrill, 1899a, Amphiomya H.L. Clark, 1939, Amphioncus H.L. Clark, 1939, Amphioplus Verrill, 1899a, Amphipholis Ljungman, 1866, Amphipholizona H.L. Clark, 1915a, Amphistigma H.L. Clark, 1938, Dougaloplus A.M. Clark, 1970, Microphiopholis Turner, 1985, Nannophiura Mortensen, 1933b, Nudamphiura Tommasi, 1965, Ophiocentrus Ljungman, 1867, Ophiocnida Lyman, 1865, Ophiodaphne Koehler, 1930, Ophionephthys Lütken, 1869, Ophiophragmus Lyman, 1865, Ophiosphaera Brock, 1888, Ophiostigma Lütken, 1856, Paracrocnida Mortensen, 1940, Paramphichondrius Guille \& Wolff, 1984, Paramphiura Koehler, 1895, Triplodia Turner \& Hallan, 2011.

\section{Diagnosis}

Dorsal disc cover variable, often naked scales, but simple spines, granules or tubercles occur in some genera. Large infradental papillae. Buccal scale higher on the oral plate than other oral papillae. Dorsalmost tooth socket a large, heart-shaped fenestration with incomplete septum, other dorsal sockets as fenestrations with septum, ventral sockets shallow, not penetrating. Oral plates with large wingshaped abradial muscle flange, often with branching ribs. Arm spine articulations with two smooth separated, parallel, straight dorsal and ventral lobes. Lateral arm plates commonly sickle-shaped with pointed dorsal tip. Lateral arm plates devoid of ornamentation except for band of more finely meshed stereom in the central part of the proximal edge. Inner side of lateral arm plates with two to three knobs instead of a ridge. 


\section{Remarks}

This large family requires revision. Preliminary findings (O'Hara et al. 2017) indicate that there are at least three major clades within the group that fit our criteria for family status. Important genera, including Amphiura, Amphioplus and Amphipholis, are polyphyletic in their current composition.

Family Amphilepididae Matsumoto, 1915

\section{Type genus}

Amphilepis Ljungman, 1867 (type species: A. norvegica (Ljungman, 1865)).

\section{Other genera}

Ophiomonas Djakonov, 1952.

\section{Diagnosis}

Tooth sockets with small, slit-shaped, perforating holes with indistinct borders. Infradental papillae minute, single wide lateral oral papilla. Arm spine articulation with two smooth ridges, connected proximally by a depressed bridge.

\section{Remarks}

This is a paedomorphic family with reduced characters.

Superfamily Ophiactoidea Ljungman, 1867

\section{Diagnosis}

Disc usually with thorny spines. Spine articulations with parallel, bent dorsal and ventral lobes.

Family Ophiothamnidae fam. nov. urn:1sid:zoobank.org:act:CD418837-0D1F-47AF-BF52-C7BC76C67EFC

\section{Type genus}

Ophiothamnus Lyman, 1869 (type species: O. vicarius Lyman, 1869).

\section{Other genera}

Histampica A.M. Clark, 1970, Ophioleila A.H. Clark, 1949.

\section{Diagnosis}

Dorsal disc with pointed spines (Ophiothamnus), naked scales (Histampica), or thorny spines (Ophioleila). Radial shields large. Infradental papillae small, distal lateral papilla at adoral shield edge widened in Ophiothamnus. Arm spine articulations with two smooth, slightly diverging ridges, not connected. Muscle and nerve openings separated by smooth bridge.

Family Ophiactidae Matsumoto, 1915

\section{Type genus}

Ophiactis Lütken, 1856 (type species: O. krebsii Lütken, 1856 = O. savignyi (Müller \& Troschel, 1842)).

\section{Other genera}

Hemipholis Lyman, 1865. 


\section{Diagnosis}

Dorsal disc with scales and plates, often with conical spines. Large tricuspid teeth. Dorsalmost tooth socket large fenestration with incomplete septum, other dorsal sockets with complete septum, ventral sockets not penetrating depressions. Infradental papillae in lateral position at dental plate. Arm spine articulation with two separated lobes, dorsal one bent and much larger than ventral one, framing two holes for muscle and nerve, separated by thin bridge. Lateral arm plates commonly with outer surface tubercles. Inner side of lateral arm plates with separate knobs sometimes associated with ridge.

\section{Remarks}

Ophiactis forms two clades based on number of lateral oral papillae (two or one), which are paraphyletic with respect to each other on some molecular topologies (O’Hara et al. 2017).

Family Ophiopholidae fam. nov. urn:1sid:zoobank.org:act:24F78A13-2640-4ACB-8D5F-EDCFFC7E3767

\section{Type genus}

Ophiopholis Müller \& Troschel, 1842 (type species: O. aculeata (Linnaeus, 1767)).

\section{Diagnosis}

Dorsal disc with large plates, encircled by small scales that are extended into multi-thorned spines in young individuals. Arm spines smooth, distally hooks and spines. Small cluster of papilliform teeth ventrally, followed by large block-like teeth dorsalwards. Tooth sockets ventrally indistinct round depressions, on middle area of dental plate horizontal ribs and depressions, dorsally fenestrations with septum. Vertebrae with narrow dorsal keel protruding beyond length of vertebra, corresponding deep dorsal groove proximally. Arm spine articulation horizontal, with two strong lobes, dorsal one larger and bent, large muscle and nerve openings. Lateral arm plates with coarse tubercles. Inner side of lateral arm plates with two separate lobes and a dorsal ridge.

\section{Family Ophiotrichidae Ljungman, 1867}

\section{Type genus}

Ophiothrix Müller \& Troschel, 1840 (type species: O. rosula (Forbes, 1839) = O. fragilis (Abildgaard in O.F. Müller, 1789)). Original type designation O. rosula by Lyman (1865). H.L. Clark (1915) synonymized $O$. rosula with $O$. pentaphyllum (Pennant, 1777) which may have caused later authors to accept the latter (older) name for the type species for some time but it was then replaced by $O$. fragilis for unknown reasons. Indeed, the name O. pentaphyllum has priority over the name $O$. fragilis and the proposal by A.M. Clark (1967) to suppress it appears never to have been decided. Prevailing usage cannot be applied because the name $O$. pentaphyllum was used as a valid species name after 1899 (ICZN article 23.9.1.1). However, to change the name of the well-known $O$. fragilis after a century of usage would not serve the purpose of nomenclatural stability. A ruling by the commission is needed.

\section{Other genera}

Gymnolophus Brock, 1888, Lissophiothrix H.L. Clark, 1938, Macrophiothrix H.L. Clark, 1938, Ophiocnemis Müller \& Troschel, 1842, Ophiogymna Ljungman, 1866, Ophiolophus MarktannerTurneretscher, 1887, Ophiomaza Lyman, 1871, Ophiophthirius Döderlein, 1898, Ophiopsammium Lyman, 1874, Ophiopteron Ludwig, 1888, Ophiothela Verrill, 1867, Ophiotrichoides Ludwig, 1882. 


\section{Diagnosis}

Dorsal disc with thorny spines or granules, arm spines thorny. Ventral half of dental plate with numerous papilliform teeth, at the outer edge as column of larger papillae, in the centre as lower granules. Dorsal teeth block-shaped. On dental plate ventral half an outer column of small holes at each edge, indistinct small depressions in the centre, dorsal half with fenestrations with septum. Infradental papillae and lateral oral papillae absent. Arm spine articulation diagonal to almost vertical, with two thick lobes, connected by thin proximal bridge, diagonal. Outer surface of lateral arm plates generally without tubercles. Inner side of lateral arm plates with three knobs. Vertebrae with narrow dorsal keel protruding distalwards far beyond vertebra edge, matching large dorsal groove proximally.

\section{Remarks}

The Ophiotrichidae forms a large, but genetically and morphologically coherent, family-level taxon. Genetic data (O'Hara et al 2017) indicates that Ophiothrix is polyphyletic and suggests that Hoggett (1991) was correct in transferring Ophiothrix species with wide dorsal arm plates into an expanded Macrophiothrix.

\section{Amphilepidida incertae sedis}

Amphicutis Pomory, Carpenter \& Winter, 2011, Ophienigma Stöhr \& Segonzac, 2005, Ophiopus Ljungman, 1867, Ophiothyreus Ljungman, 1872.

\section{Discussion}

The purpose of the proposed new classification is above all to facilitate human communication. It is based as much as possible on inferred phylogenetic relationships but hierarchic ranks will always remain artificial. The latest morphological phylogeny (Thuy \& Stöhr 2016) identified the superorders Euryophiurida and Ophintegrida along with several of the orders and lower ranks but, due to the considerably smaller dataset and the high degree of paedomorphosis in some groups (e.g., Ophiurida), the resolution of the tree was lower. Therefore, molecular data (O'Hara et al. 2017) were instrumental in the recognition of the phylogenetic clades that are here proposed as taxonomic ranks. Once the clades were identified, it was possible to make sense of morphological characters. Structures that were previously regarded as variation within a group are now recognized as key characters for separate taxa. The large number of genera still without placement is caused by lack of data, both morphological and molecular. Many of these are rare and difficult to obtain. The few known specimens may not be available for the destructive techniques that were used to collect the data for this study. Advancements in non-destructive techniques such as 3D imaging by x-ray microcomputed tomography (Landschoff \& Griffith 2015; Okanishi et al. 2017), x-ray microscopy and synchrotron imaging open up possibilities for future examinations that may close the present information gaps. The current knowledge on ophiuroid morphology is still quite limited but recent studies (Martynov 2010b; Thuy \& Stöhr 2011, 2016) have shown that a wealth of new information can be collected with new approaches.

The new classification recognizes 33 families, a major increase from the hitherto accepted 19 families (Stöhr et al. 2017) (Fig. 1). It differs greatly from the latest, until now widely accepted, classification proposed by Smith et al. (1995), which had some drawbacks and limitations (Stöhr 2012). The new classification's greatest advantage is the strong support of a large molecular analysis (O'Hara et al. 2017) that suggests monophyly for the proposed taxa. On lower taxonomic level, more work is needed. The most heterogeneous families may turn out to contain monophyletic groups that may be placed on subfamily level. Several genera are suspected to be non-monophyletic in their current species composition and further analysis is needed. Identification tools, such as interactive keys, will be produced in the future. 


\section{Acknowledgements}

$\mathrm{TOH}$ and $\mathrm{AH}$ were supported by the Marine Biodiversity Hub, funded through the National Environmental Research Program (NERP), and administered through the Australian Government's Department of the Environment. SS was supported by Riksmusei Vänner and Längmanska Kulturfonden (SEM studies). AM was supported by a research project of MSU Zoological Museum (AAAA-A16-116021660077-3, depository of specimens) and Russian Science Foundation Grant 14-50-00029 (SEM study). We thank two anonymous referees for helpful comments.

\section{References}

Baker A.N. 2016. An illustrated catalogue of type specimens of the bathyal brittlestar genera Ophiomusium Lyman and Ophiosphalma H.L. Clark (Echinodermata: Ophiuroidea). Zootaxa 4097: 1-40. https://doi.org/10.11646/zootaxa.4097.1.1

Benavides-Serrato M. \& O'Hara T.D. 2008. A new species in the Ophiocoma erinaceus complex from the South-west Pacific Ocean (Echinodermata: Ophiuroidea: Ophiocomidae). Memoirs of Museum Victoria 65: 51-56. https://doi.org/10.24199/j.mmv.2008.65.4

Clark A.M. 1967. Proposals for stabilization of the names of some common European Ophiuroidea Z.N.(S.) 1772. The Bulletin of Zoological Nomenclature 24: 41-49.

Clark A.M. \& Rowe F.W.E. 1971. Monograph of Shallow-water Indo-west Pacific Echinoderms. Trustees of the British Museum (Natural History), London.

Clark H.L. 1915. Catalogue of recent Ophiurans. Memoirs of the Museum of Comparative Zoology 25: 163-376.

Devaney D.M. 1970. Studies on ophiocomid brittlestars. I. A new genus (Clarkcoma) of Ophiocominae with a reevaluation of the genus Ophiocoma. Smithsonian Contributions to Zoology 51: 1-41. https://doi.org/10.5479/si.00810282.51

Hendler G. 1978. Development of Amphioplus abditus (Verrill) (Echinodermata: Ophiuroidea). II. Description and discussion of ophiuroid skeletal ontogeny and homologies. Biological Bulletin 174: 20-29. https://doi.org/10.2307/1540776

Hertz M. 1927. Die Ophiuroiden der deutschen Tiefsee-Expedition. 1. Chilophiurida Mats. (Ophiolepididae: Ophioleucidae: Ophiodermatidae: Ophiocomidae). Wissenschaftliche Ergebnisse der deutschen Tiefsee-Expedition auf dem Dampfer "Valdivia” 1898-1899 22: 59-122.

Hoggett A.K. 1991. The genus Macrophiothrix (Ophiuroidea: Ophiotrichidae) in Australian waters. Invertebrate Taxonomy 4: 1077-1146. https://doi.org/10.1071/it9901077

Krell F.-T. 2015. A mixed bag: when are early online publications available for nomenclatural purposes? Bulletin of Zoological Nomenclature 72: 19-32. https://doi.org/10.21805/bzn.v72i1.a14

Landschoff J. \& Griffith C.L. 2015. Three-dimensional visualisation of brooding behaviour in two distantly related brittle stars from South African waters. African Journal of Marine Science 37 (4): 533-541. https://doi.org/10.2989/1814232X.2015.1095801

Lyman T. 1865. Ophiuridae and Astrophytidae. Illustrated Catalogue of the Museum of Comparative Zoology at Harvard College 1: 1-200. https://doi.org/10.5962/bhl.title.40077

Lyman T. 1869. Preliminary report on the Ophiuridae and Astrophytidae dredged in deep water between Cuba and Florida Reef. Bulletin of the Museum of Comparative Zoology 1: 309-354.

Lyman T. 1874. Ophiuridae and Astrophytidae, new and old. Bulletin of the Museum of Comparative Zoology at Harvard College, Cambridge 3: 221-272. 
Lyman T. 1879. Ophiuridae and Astrophytidae of the "Challenger" expedition. Part II. Bulletin of the Museum of Comparative Zoology at Harvard 6: 17-83.

Martynov A.V. 2010a. Structure of the arm spine articulation ridges as a basis for taxonomy of Ophiuroidea (a preliminary report). In: Harris L., Böttger S.A., Walker C.W. \& M.P. Lesser M.P. (eds) Echinoderms: Durham. Proceedings of the 12 ${ }^{\text {th }}$ International Echinoderm Conference, Durham, New Hampshire, USA, 7-11 August 2006: 233-239. CRC Press, Taylor \& Francis, Boca Raton, London, New York, Leiden.

Martynov A.V. 2010b. Reassessment of the classification of the Ophiuroidea (Echinodermata), based on morphological characters. I. General character evaluation and delineation of the families Ophiomyxidae and Ophiacanthidae. Zootaxa 2697: 1-154.

Martynov A.V. \& Litvinova N.M. 2008. Deep-water Ophiuroidea of the northern Atlantic with descriptions of three new species and taxonomic remarks on certain genera and species. Marine Biology Research 4: 76-111. https://doi.org/10.1080/17451000701840066

Meier R. 2017. Citation of taxonomic publications: the why, when, what and what not. Systematic Entomology 42: 301-304. https://doi.org/10.1111/syen.12215

Mortensen T. 1927. Handbook of the Echinoderms of the British Isles. Backhuys, Rotterdam.

Mortensen T. 1933. Studies of Indo-Pacific Euryalids. Videnskabelige Meddelelser fra Dansk naturhistorisk Forening 96 (2): 1-75.

Naughton K.M., O’Hara T.D., Appleton B. \& Cisternas P.A. 2014. Antitropical distributions and species delimitation in a group of ophiocomid brittle stars (Echinodermata: Ophiuroidea: Ophiocomidae). Molecular Phylogenetics and Evolution 78: 232-244. https://doi.org/10.1016/j.ympev.2014.05.020

O’Hara T.D. \& Stöhr S. 2006. Deep water Ophiuroidea (Echinodermata) of New Caledonia: Ophiacanthidae and Hemieuryalidae. In: Richer de Forges B. \& Justine J.-L. (eds) Tropical DeepSea Benthos 24: 33-141. Mémoires du Muséum national d'Histoire naturelle 193, Muséum national d'Histoire naturelle, Paris.

O'Hara T.D., Byrne M. \& Cisternas P. 2004. The Ophiocoma erinaceus complex: another case of cryptic speciation in echinoderms. In: Heinzeller T \&. Nebelsick J.H. (eds) Echinoderms: München. Proceedings of the 11 th International Echinoderm Conference, Munich, 6-10 October 2003: 537-542. Balkema, Munich.

O’Hara T.D., Hugall A.F., Thuy B. \& Moussalli A. 2014. Phylogenomic resolution of the class Ophiuroidea unlocks a global microfossil record. Current Biology 24: 1874-1879.

https://doi.org/10.1016/j.cub.2014.06.060

O’Hara T.D., Hugall A.F., Thuy B., Stöhr S. \& Martynov A.V. 2017. Restructuring higher taxonomy using broad-scale phylogenomics: the living Ophiuroidea. Molecular Phylogenetics and Evolution 107: 415-430. https://doi.org/10.1016/j.ympev.2016.12.006

Okanishi M. \& Fujita T. 2009. A new species of Asteroschema (Echinodermata: Ophiuroidea: Asteroschematidae) from Southwestern Japan. Species Diversity 14: 115-129.

Okanishi M. \& Fujita T. 2011. A taxonomic review of the genus Astrocharis Koehler (Echinodermata: Ophiuroidea: Asteroschematidae), with a description of a new species. Zoological Science 28: 148-157. https://doi.org/10.2108/zsj.28.148

Okanishi M., O’Hara T.D. \& Fujita T. 2011a. A new genus Squamophis of Asteroschematidae (Echinodermata: Ophiuroidea: Euryalida) from Australia. Zookeys 129: 1-15.

https://doi.org/10.3897/zookeys.129.1202 
Okanishi M., O'Hara T.D. \& Fujita T. 2011b. Molecular phylogeny of the order Euryalida (Echinodermata: Ophiuroidea), based on mitochondrial and nuclear ribosomal genes. Molecular Phylogenetics and Evolution 61: 392-399. https://doi.org/10.1016/j.ympev.2011.07.003

Okanishi M., Olbers J. \& Fujita T. 2013. A taxonomic review of the genus Asteromorpha Lütken (Echinodermata: Ophiuroidea: Euryalidae). The Raffles Bulletin of Zoology 61: 461-480.

Okanishi M., Fujita T., Maekawa Y. \& Sasaki T. 2017. Non-destructive morphological observations of the fleshy brittle star, Asteronyx loveni using micro-computed tomography (Echinodermata, Ophiuroidea, Euryalida). Zookeys 663: 1-19. https://doi.org/10.3897/zookeys.663.11413

Parameswaran U.V., Abdul Jaleel K.U., Gopal A., Sanjeevan V.N. \& Vijayan A.K. 2016. On an unusual shallow occurrence of the deep-sea brittle star Ophiomyces delata in the Duncan Passage, Andaman Islands (Northern Indian Ocean). Marine Biodiversity 46 (1): 151-156.

https://doi.org/10.1007/s12526-015-0344-6

Paterson G.L.J. 1985. The deep-sea Ophiuroidea of the North Atlantic Ocean. Bulletin of the British Museum (Natural History), Zoology Series 49: 1-162.

Pineda-Enriquez T., Solis-Marin F.A. \& Laguarda-Figueras A. 2014. Revision of the genus Ophioteichus H.L. Clark, 1938 (Ophiuroidea: Ophiolepididae). Zootaxa 3784: 241-250.

https://doi.org/10.11646/zootaxa.3784.3.3

Smith A.B., Paterson G.L.J. \& Lafay B. 1995. Ophiuroid phylogeny and higher taxonomy: morphological, molecular and palaeontological perspectives. Zoological Journal of the Linnean Society 114: 213-243. https://doi.org/10.1111/j.1096-3642.1995.tb00117c.x

Stöhr S. 2005. Who's who among baby brittle stars (Echinodermata: Ophiuroidea): postmetamorphic development of some North Atlantic forms. Zoological Journal of the Linnean Society 143: 543-576. https://doi.org/10.1111/j.1096-3642.2005.00155.x

Stöhr S. 2011. New records and new species of Ophiuroidea (Echinodermata) from Lifou, Loyalty Islands, New Caledonia. Zootaxa 3089: 1-50.

Stöhr S. 2012. Ophiuroid (Echinodermata) systematics - where do we come from, where do we stand and where should we go? In: Kroh A. \& Reich M. (eds) Echinoderm Research 2010: Proceedings of the Seventh European Conference on Echinoderms, Göttingen, Germany, 2-9 October 2010. Zoosymposia 7: $147-161$.

Stöhr S. \& Martynov A. 2016. Paedomorphosis as an evolutionary driving force: insights from deep-sea brittle stars. PLoS One 11 (11): e0164562. https://doi.org/10.1371/journal.pone.0164562

Stöhr S. \& Muths D. 2010. Morphological diagnosis of the two genetic lineages of Acrocnida brachiata (Echinodermata: Ophiuroidea) with description of a new species. Journal of the Marine Biology Association U.K. 90: 831-843. https://doi.org/10.1017/S0025315409990749

Stöhr S. \& Segonzac M. 2005. Deep-sea ophiuroids (Echinodermata) from reducing and non-reducing environments in the North Atlantic Ocean. Journal of the Marine Biological Association U.K. 85: 383402. https://doi.org/10.1017/S0025315405011318h

Stöhr S., Conand C. \& Boissin E. 2008. Brittle stars (Echinodermata: Ophiuroidea) from La Réunion and the systematic position of Ophiocanops Koehler, 1922. Zoological Journal of the Linnean Society 153: 545-560. https://doi.org/10.1111/j.1096-3642.2008.00401.x

Stöhr S., Boissin E. \& Chenuil A. 2009. Potential cryptic speciation in Mediterranean populations of Ophioderma (Echinodermata: Ophiuroidea). Zootaxa 2071: 1-20. 
Stöhr S., O'Hara T.D. \& Thuy B. 2012. Global diversity of brittle stars (Echinodermata: Ophiuroidea). PLoS One 7 (3): e31940. https://doi.org/10.1371/journal.pone.0031940

Stöhr S., O’Hara T.D. \& Thuy B. 2017. World Ophiuroidea Database. World Ophiuroidea Database. Available from http://www.marinespecies.org/ophiuroidea [accessed 12 Jul. 2017].

Sumida P.Y.G., Tyler P.A., Gage J.D. \& Nørrevang A. 1998. Postlarval development in shallow and deep-sea ophiuroids (Echinodermata: Ophiuroidea) of the NE Atlantic Ocean. Zoological Journal of the Linnean Society 124: 267-300. https://doi.org/10.1111/j.1096-3642.1998.tb00577.x

Thuy B. 2013. Temporary expansion to shelf depths rather than an onshore-offshore trend: the shallowwater rise and demise of the modern deep-sea brittle star family Ophiacanthidae (Echinodermata: Ophiuroidea). European Journal of Taxonomy 48: 1-242. https://doi.org/10.5852/ejt.2013.48

Thuy B. \& Meyer C.A. 2013. The pitfalls of extrapolating modern depth ranges to fossil assemblages: new insights from Middle Jurassic brittle stars (Echinodermata: Ophiuroidea) from Switzerland. Swiss Journal of Palaeontology 132: 5-21. https://doi.org/10.1007/s13358-012-0048-5

Thuy B. \& Stöhr S. 2011. Lateral arm plate morphology in extant brittle stars (Echinodermata) and its application in micropalaeontology. Zootaxa 3013: 1-47.

Thuy B. \& Stöhr S. 2016. A new morphological phylogeny of the Ophiuroidea (Echinodermata) accords with molecular evidence and renders microfossils accessible for cladistics. PLoS One 11 (5): e0156140. https://doi.org/10.1371/journal.pone.0156140

Manuscript received: 13 July 2017

Manuscript accepted: 11 September 2017

Published on: 21 March 2018

Topic editor: Rudy Jocqué

Desk editor: Kristiaan Hoedemakers

Printed versions of all papers are also deposited in the libraries of the institutes that are members of the EJT consortium: Muséum national d'Histoire naturelle, Paris, France; Botanic Garden Meise, Belgium; Royal Museum for Central Africa, Tervuren, Belgium; Natural History Museum, London, United Kingdom; Royal Belgian Institute of Natural Sciences, Brussels, Belgium; Natural History Museum of Denmark, Copenhagen, Denmark; Naturalis Biodiversity Center, Leiden, the Netherlands; Museo Nacional de Ciencias Naturales-CSIC, Madrid, Spain; Real Jardín Botánico de Madrid CSIC, Spain. 


\section{Appendix A}

\section{References to original descriptions of Ophiuroidea taxa, mentioned in the new classification}

Abildgaard P.C. 1789. In: Müller O.F. (ed.) Zoologica Danica seu Animalium Daniae et Norwegiae rariorum ac minus notoruum. Descritiones et Historia. N. Mölleri/ N. Christensen, Hauniae.

Agassiz L. 1836. Prodrome d'une monographie des radiaires ou Echinodermes. Mémoires de la Société des Sciences Naturelle de Neuchâtel 1: 168-199.

Baker A.N. 1980. Euryalinid Ophiuroidea (Echinodermata) from Australia, New Zealand, and the southwest Pacific Ocean. New Zealand Journal of Zoology 7: 11-83.

Bell F.J. 1884. Echinodermata. In: Coppinger R.W. (ed.) Report on the Zoological Collections made in the Indo-Pacific during the voyage of H.M.S. Alert 1881-2: 117-177, 509-512, pls 8-17, 45. Trustees of the British Museum (Natural History), London.

Bell F.J. 1894. On the echinoderms collected during the voyage of H.M.S. Penguin and by H.M.S. Egeria, when surveying Macclesfield Bank. Proceedings of the Zoological Society of London, 1894: $392-413$.

Bell F.J. 1902. Echinodermata. Reports on the collections of Natural History made in the Antarctic regions during the voyage of the "Southern Cross 8: 214-220, 2 pls.

Belyaev G.M. \& Litvinova N.M. 1972. New genera and species of deep sea Ophiuroidea. Byulleten' Moskovskogo Obshchestva Ispytatelei Prirody. Otdel Biologicheskiy 3: 5-20.

Belyaev G.M. \& Litvinova N.M. 1976. The new and rare ophiuroid species from the Pacific and Indian Oceans. Trudy Instituta Okeanologii Akademija nauk CCCP 99: 126-139.

Blainville H.-M.D. de. 1834. Manuel d'actinologie ou de zoophytologie. Levrault, Paris.

Brock J. 1888. Die Ophiuridenfauna des indischen Archipels. Zeitschrift für wissenschaftliche Zoologie 47: 465-539.

Bruguière J.G. 1791. Histoire naturelle des vers. Échinodermes. Encyclopédie Méthodique, tome 1. Panckucke, Paris.

Bruzelius N. 1805. Dissertatio sistens species cognitas asteriarum, quamr. sub praesidio D.M. and. J. Retzii, pro laurea modeste exhibet Nicolaus Bruzelius. Lundae.

Cherbonnier G. \& Guille A. 1978. Echinodermes: Ophiurides. Centre National de la Recherche Scientifique, Paris.

Clark A.H. 1916. Ophiomaria, a new genus of Ophiurans from Southern South America and the adjacent portion of the Antarctic Continent. Journal of the Washington Academy of Sciences 6: 384-387.

Clark A.H. 1934. A new genus of brittle star from Puerto Rico. Smithsonian Miscellaneous Collections 91: $1-3$.

Clark A.H. 1939a. Echinoderms (other than holothurians) collected on the Presidential Cruise of 1938. Smithsonian Miscellaneous Collections 98: 1-16, pls. 1-5.

Clark A.H. 1949. Ophiuroidea of the Hawaiian Islands. Bulletin of the Bernice P. Bishop Museum 195: $3-133$.

Clark A.H. 1952. Schizostella, a new genus of brittle-star (Gorgonocephalidae). Proceedings of the United States National Museum 102: 451-454, plate 40. https://doi.org/10.5479/si.00963801.1023307.451 
Clark A.M. 1970. Notes on the family Amphiuridae (Ophiuroidea). Bulletin of the British Museum (Natural History), Zoology 19: 1-81.

Clark H.L. 1908. Some Japanese and East Indian echinoderms. Bulletin of the Museum of Comparative Zoology at Harvard 51: 279-311.

Clark H.L. 1909a. Scientific results of the trawling expedition of H.M.C.S. "Thetis" off the coast of New South Wales, in February and March 1898. Echinodermata. Memoirs of the Australian Museum 4: 519-564.

Clark H.L. 1909b. Notes on some Australian and Indo-Pacific echinoderms. Bulletin of the Museum of Comparative Zoology at Harvard University 52: 109-135.

Clark H.L. 1911. North Pacific Ophiurans in the collection of the United States National Museum. Smithsonian Institution United States National Museum Bulletin 75: 1-302.

Clark H.L. 1913. Scientific Results of the Expedition to the Gulf of California in charge of C.H. Townsend, by the U.S. Fisheries Steamship 'Albatross' in 1911. Commander C.H. Burrage, U.S.N., Commanding. V. Echinoderms from Lower California, with descriptions of new species. Bulletin of the American Museum of Natural History 32: 185-236.

Clark H.L. 1914. The echinoderms of the Western Australian Museum. Records of the Western Australian Museum 1: 132-173.

Clark H.L. 1915a. Catalogue of recent Ophiurans. Memoirs of the Museum of Comparative Zoology 25: 163-376.

Clark H.L. 1915b. A remarkable new brittle star. Journal of Entomology and Zoology 7: 64-66.

Clark H.L. 1917. Reports on the Scientific Results of the Albatross Expedition to the Tropical Pacific, 1899-1900 (Part 18). Reports on the Scientific results of the Albatross Expedition to the Eastern Tropical Pacific, 1904-1905 (Part 30). Ophiuroidea. Bulletin of the Museum of Comparative Zoölogy at Harvard College, Cambridge 61: 429-453.

Clark H.L. 1923. The echinoderm fauna of South Africa. Annals of the South African Museum 13: 221-435.

Clark H.L. 1928. The sea-lilies, sea-stars, brittle-stars and sea-urchins of the South Australian Museum. Records of the South Australian Museum 3: 361-428.

Clark H.L. 1938. Echinoderms from Australia. An account of collections made in 1929 and 1932. Memoirs of the Museum of Comparative Zoology, at Harvard College, Cambridge, Mass. 55: 1-596, pls 1-28. https://doi.org/10.5962/bhl.title.49349

Clark H.L. 1939b. Ophiuroidea. Scientific Reports from the John Murray Exp. 1933-34 6: 1-136.

Clark H.L. 1941. Reports on the scientific results of the Atlantis expeditions to the West Indies, under the joint auspices of the University of Havana and Harvard University. The echinoderms (other than Holothurians). Memorias de la Sociedad cubana de Historia natural, "Felipe Poey" 15: 1-154.

Danielssen D.C. \& Koren J. 1877. Fra den norske Nordhavsexpedition: Echinodermes. Nyt Magazin for Naturvidenskaberne 23: 45-83.

Devaney D.M. 1970. Studies on ophiocomid brittlestars. I. A new genus (Clarkcoma) of Ophiocominae with a reevaluation of the genus Ophiocoma. Smithsonian Contributions to Zoology 51: 1-41. https://doi.org/10.5479/si.00810282.51

Djakonov A.M. 1952. Echinoderms from abyssal depth in the water around Kamtchatka. Issledovaniya dal'nevostochnykh morei: Investigations Far East Seas USSR 3: 116-130. 
Döderlein L. 1898. Über einige epizoisch lebende Ophiuroidea. Zoologische Forschungsreisen in Australien und dem Malayischen Archipel. Denkschriften der Medicinisch-Naturwissenschaftlichen Gesellschaft zu Jena 5: 483-488, pl. 37.

Döderlein L. 1911. Über japanische und andere Euryalae. Abhandlungen der math. phys. Klasse der KOniglichen Bayerischen Akademie der Wissenschaften 5: 1-123, pls 1-9.

Döderlein L. 1927. Indopacifische Euryale. Abhandlungen der Bayerische Akademie der Wissenschaften 31: $1-105$, pls $1-10$.

Döderlein L. 1930. 2. Euryale. In: Die Ophiuroiden der Deutschen Tiefsee-Expedition. Wissenschaftliche Ergebnisse der Deutschen Tiefsee-Expedition auf dem Dampfer "Valdivia" 1898-1899: 348-396, pls $14-16$.

Downey M.E. 1967. Astronebris tatafilius (Euryale: Asteronychidae), a new genus and species of ophiuroid from the Aleutians, with a revised key to the family Asteronychidae. Proceedings of the Biological Society of Washington 80: 41-46.

Fell H.B. 1961a. New genera and species of Ophiuroidea from Antarctica. Transactions of the Royal Society of New Zealand 88: 839-841.

Fell H.B. 1961b. The Fauna of the Ross Sea .Part 1, Ophiuroidea. Memoirs of the New Zealand Oceanographic Institute 18: 9-79, 19 pls.

Fleming J. 1828. An History of British Animals Exhibiting their Descriptive Characters and Systematical Arrangement of Genera and Species of Quadrupeds, Birds, Reptiles, Fishes, Mollusca, and Radiata of the United Kingdom. Bell \& Bradfute, Edinburgh.

Forbes E. 1843. On the radiata of the eastern Mediterranean. Transactions of the Linnean Society of London 19: 143-153. https://doi.org/10.1111/j.1096-3642.1842.tb00360.x

Gislén T. 1926. On the generic types of the ophiurid genus Ophiocentrus Ljungman (Amphiocnida Verrill). Göteborgs Kungliga Vetenskaps- och Vitterhets-Samhälles Handlingar. Fjärde Följden 30: $1-16$.

Gray J.E. 1840. Room II. In: Synopsis of the contents of the British Museum: 57-65. British Museum, London.

Grube A.E. 1868. Über einige seltenere oder neue Ophiuriden. Jahresberichte der schlesischen Gesellschaft für vaterländische Kultur 45: 44-45.

Guille A. 1982. Papers from the Echinoderm Conference. 5. A new genus and species of ophiacanthid brittlestar (Echinodermata: Ophiuroidea) from the Kerguelen Islands, with new taxonomic, biogeographic and quantitative data on the echinoderm fauna. Australian Museum Memoir 16: 67-87.

https://doi.org/10.3853/j.0067-1967.16.1982.359

Guille A. \& Wolff W.J. 1984. Résultats biologiques de l'Expédition Snellius Echinodermata: Ophiuroidea I. Zoologische Verhandelingen 213: 1-39.

Hertz M. 1927. Die Ophiuroiden der deutschen Tiefsee-Expedition. 1. Chilophiurida Mats. (Ophiolepididae: Ophioleucidae: Ophiodermatidae: Ophiocomidae). Wissenschaftliche Ergebnisse der deutschen Tiefsee-Expedition auf dem Dampfer "Valdivia" 1898-1899 22: 59-122, pls 6-9.

Hill A. 1940. Anew genus of brittle stars, Amphicontus. Reports of the Alllan Hancock Pacific Expedition, 1932-38 8: 1-4, pl. 1.

Ives J.E. 1889. On a New Genus and Two New Species of Ophiurans. Proceedings of the Academy of Natural Sciences of Philadelphia 41: 143-145. 
Koehler R. 1895. Notes échinologiques. Revue biologique du Nord de la France 7: 317-342, pl. 9.

Koehler R. 1897. Echinodermes recueillis par “"l'Investigator”" dans l'Ocean Indien. I. Les Ophiures de mer profonde. Annales des Sciences Naturelles Zoologie, series 8 4: 277-372, pl. 5-9.

Koehler R. 1898. Échinodermes, receuillis par l'Investigator dans l'Océan Indien. II. Les ophiures littorales. Bulletin Scientique de la France et de la Belgique 31: 55-124.

Koehler R. 1901. Note préliminaire sur quelques ophiures nouvelles provenant des campagnes de la Princesse Alice. Bulletin de la Société zoologique de France 26: 222-231.

Koehler R. 1904. Ophiures de mer profonde. Siboga Expeditie Monographs 45a: 1-176, pls 1-36.

Koehler R. 1905. Ophiures littorales. Siboga Expeditie Monographs 45b: 1-140, pls. 1-18.

Koehler R. 1906. Description des ophiures nouvelles recueillies par le Travailleur et le Talisman. Mémoires de la Société Zoologique de France 19: 279-351, pls 10-14.

Koehler R. 1907. Note preliminaire sur quelque Asteries et Ophiures provenant des compagnes de la Princesse Alice. Bulletin de l'Institut Océanographique 99: 1-47.

Koehler R. 1912. Echinodermes (Asteries, Ophiures et Echinides). In: (eds) Deuxième Expédition Antarctique Française (1908-1910) commandé par le Dr Jean Charcot: 272, 16 pls. Masson, Paris.

Koehler R. 1914. A contribution to the study of Ophiurans of the United States National Museum. Bulletin of the United States National Museum 84: 1-173.

Koehler R. 1922a. Ophiurans of the Philippine Seas and adjacent waters. Smithsonian Institution United States National Museum Bulletin 100: 1-486.

Koehler R. 1922b. Echinodermata: Ophiuroidea. Australasian Antarctic Expedition Series C 8: 1-98, pls 76-90. https://doi.org/10.5962/bhl.title. 11722

Koehler R. 1923. Astéries et Ophiures recueillies par l'Expédition Antarctique Suédoise (1901-1903). Further Zoological Results of the Swedish Antarctic Expedition 1901-1903 1: 1-145.

Koehler R. 1930. Ophiures recueillies par le Docteur Th. Mortensen dans les Mers d'Australie et dans l'Archipel Malais. Papers from Dr. Th. Mortensen's Pacific Expedition 1914-16. LIV. Videnskabelige Meddelelser fra Dansk naturhistorisk Forening 89: 1-295.

Lamarck J.B. 1801. Système des animaux sans vertèbres; ou tableau général des classes, des orres et des genres de ces animaux. Deterville, Paris.

Lamarck J.B. de 1816. Histoire naturelle des animaux sans vertèbres. L'Imprimerie d'Abel Lanoe, Paris.

Linnaeus C. 1758. Systema naturce per regna tria naturce, secundum classes, ordines, genera, species, cum characteribus, differentiis, synonymis, locis, $10^{\text {th }}$ edn. Holmiae, Stockholm.

Linnaeus C. 1767. Systema Naturae per Regna Tria Naturae, Secundum Classes Ordines, Genera, Species, cum Characteribus, Differentiis, Synonymis, Locis. Tomus I. Editio Duodecima. Reformata. Holmiae, Stockholm.

Ljungman A.V. 1865. Tillägg till kännedom af Skandinaviens Ophiurider. Öfversigt af Kongliga Vetenskaps-Akademiens Förhandlingar 1863 21: 359-367, XV.

Ljungman A.V. 1866. Om några nya arter af Ophiurider. Öfversigt af Kongliga Vetenskaps-Akademiens Förhandlingar 1866 23: 163-166.

Ljungman A.V. 1867. Ophiuroidea viventia huc usque cognita. Öfversigt af Kungliga VetenskapsAkademiens Förhandlingar 1866 23: 303-336. 
Ljungman A.V. 1872. Förteckning öfver uti Vestindien af Dr A. Goës samt under korvetten Josefinas expedition i Atlantiska Oceanen samlade Ophiurider. Öfversigt af Kungliga Vetenskapsakademiens Förhandlingar 1871 6: 615-658.

Ludwig H. 1882. Verzeichnis der von Prof. Ed. van Beneden an der Küste von Brazilien gesammelten Echinodermen. Mémoires couronnés et mémoires des savants étrangers / publiés par l'Académie royale des sciences, des lettres et des beaux-arts de Belgique 44: 1-26.

Ludwig H. 1888. Ophiopteron elegans, eine neue, wahrscheinlich schwimmende Ophiuridenform. Zeitschrift für wissenschaftliche Zoologie 47: 459-464, pl. 35.

Lütken C.F. 1855. Bidrag til Kundskab om Slangestjernerne. I. Forelöbig Oversigt over Grönlandshavets Ophiurer. Videnskabelige Meddelelser fra Dansk Naturhistorisk Forening, 1854: 95-104.

Lütken C.F. 1856. Bidrag til kundskab om Slangestjernerne. II. Oversigt over de vestindiske Ophiurer. Videnskabelige Meddelelser fra Dansk Naturhistorisk Förening i Kjøbenhavn 1856 8: 1-19.

Lütken C.F. 1859. Additamenta ad historiam Ophiuridarum. 2. Beskrivelser af nye eller hidtil kun ufoldstaendigt kjendte Arter af Slangestjerner. Kongelige Danske Videnskabernes Selskabs Skrifter 5: 179-271, pls 1-5.

Lütken C.F. 1869. Additamenta ad historiam Ophiuridarum. 3. Beskrivende og kritiske Bidrag til Kundskab om Slangestjernerne. Det kongelige danske Videnskabernes Selskabs Skrifter 5: 24-109.

Lütken C.F. \& Mortensen T. 1899. Reports on an exploration off the west coasts of Mexico, Central and South America, and off the Galapagos Islands, in charge of Alexander Agassiz by the U.S. Fish Commission steamer Albatross, during 1891, Lieut. Commander Z.L. Tanner, U.S.N., commanding. XXV. The Ophiuridae. Memoirs of the Museum of Comparative Zoology 23: 93-208, pls 1-23. https://doi.org/10.5962/bhl.title.65637

Lyman T. 1861. Descriptions of new Ophiuridae. Proceedings of the Boston Society of Natural History 1859-61 8: 75-86.

Lyman T. 1869. Preliminary report on the Ophiuridae and Astrophytidae dredged in deep water between Cuba and Florida Reef. Bulletin of the Museum of Comparative Zoology 1: 309-354.

Lyman T. 1872. Note sur les Ophiurides et Euryales qui se trouvant les collections de Muséum d'Histoire Naturelle de Paris. Annales des Sciences Naturelles, series 5, Zoologie 16: 1-8.

Lyman T. 1875. Zoological results of the Hassler Expedition. 2. Ophiuridae and Astrophytidae. Illustrated catalogue of the Museum of Comparative Zoology at Harvard College 8: 1-34, 5 pls.

Lyman T. 1878a. Ophiuridae and Astrophytidae of the "Challenger" expedition. Part I. Bulletin of the Museum of Comparative Zoology at Harvard 5: 65-168.

Lyman T. 1878b. Ophiurans and Astrophytons. Reports on the dredging operations of the U.S. coast survey Str. "Blake". Bulletin of the Museum of Comparative Zoology at Harvard 5: 217-238, 3 pls.

Lyman T. 1879. Ophiuridae and Astrophytidae of the "Challenger" expedition. Part II. Bulletin of the Museum of Comparative Zoology at Harvard 6: 17-83.

Lyman T. 1880. A structural feature hitherto unknown among Echinodermata found in deep-sea ophiurans. Anniversary Memoirs of the Boston Society of Natural History, 1880: 1-12, pls 1-2.

Lyman T. 1883. Reports on the results of dredging, under the supervision of Alexander Agassiz, in the Carribbean Sea (1878-79), and on the east coast of the United States, during the summer of 1880, by the U.S. coast survey steamer "Blake", commander J.R. Bartlett U.S.N., commanding. XX.- Report on the Ophiuroidea. Bulletin of the Museum of Comparative Zoology at Harvard 10: 227-287. 
Madsen F.J. 1983. A review of the Ophioleucinae stat. rev. (Echinodermata, Ophiuroidea) with the erection of a new genus, Ophiostriatus. Steenstrupia 9: 29-69.

Marktanner-Turneretscher G. 1887. Beschreibung neuer Ophiuriden und Bemerkungen zu bekannten. Annalen des königlich kaiserlichen naturhistorischen Hofmuseums 2: 291-316.

Martens E. von. 1867. Über vier neue Schlangensterne, Ophiuren, des Kgl. zoologischen Museums. Monatsberichte der deutschen Akademie der Wissenschaften, Berlin 1867: 345-348.

Martynov A.V. 2010. Reassessment of the classification of the Ophiuroidea (Echinodermata), based on morphological characters. I. General character evaluation and delineation of the families Ophiomyxidae and Ophiacanthidae. Zootaxa 2697: 1-154.

Matsumoto H. 1913. Evolutionary history of the class Ophiuroidea and a note on the new classification of the class. Zoological Magazine 25: 521-527. [In Japanese.]

Matsumoto H. 1915. A new classification of the Ophiuroidea: with descriptions of new genera and species. Proceedings of the Academy of Natural Sciences, Philadelphia 67: 43-92.

Matsumoto H. 1917. A monograph of Japanese Ophiuroidea, arranged according to a new classification. Journal of the College of Science, Imperial University, Tokyo 38: 1-408.

McKnight D.G. 2000. The Marine Fauna of New Zealand: Basket-stars and Snake-stars (Echinodermata: Ophiuroidea: Euryalinida). National Institute of Water and Atmospheric Research, Auckland, New Zealand.

Mortensen T. 1910. Microphiura decipiens n.g., n.sp., a remarkable new West Indian ophiurid. Videnskabelige Meddelelser fra Dansk Naturhistorisk Forening, 1910: 203-209.

Mortensen T. 1913. Some new echinoderms from Greenland. Videnskabelige Meddelelser fra Dansk Naturhistorisk Forening 66: 37-43.

Mortensen T. 1920. Notes on some Scandinavian echinoderms, with descriptions of two new ophiurid. Videnskabelige Meddelelser fra Dansk Naturhistorisk Forening 72: 45-79.

Mortensen T. 1932. On an extraordinary ophiurid, Ophiocanops fugiens Koehler. With remarks on Astrogymnotes, Ophiopteron, and on an albino Ophiocoma. Videnskabelige Meddelelser fra Dansk Naturhistorisk Forening 93: 1-22.

Mortensen T. 1933. Echinoderms of South Africa (Asteroidea and Ophiuroidea). Videnskabelige Meddelelser fra Dansk Naturhistorisk Forening 93: 215-400.

Mortensen T. 1936. Echinoidea and Ophiuroidea. Discovery Report 12: 199-348.

Mortensen T. 1940. Echinoderms from the Iranian Gulf. Asteroidea, Ophiuroidea, and Echinoidea. Danish Scientific Investigations in Iran, Part 2: 55-112.

Müller J. \& Troschel F.H. 1840. Über die Gattungen der Ophiuren. Archiv Für Naturgeschichte. Berlin 6: $326-330$.

Müller J.H. \& Troschel F.H. 1842. System der Asteriden. Vieweg \& Sohn, Braunschweig.

Murakami S. 1943. Report on the ophiurans of Palao, Caroline Island. Journal of the Department of Agriculture, Kyûshû Imperial University 7: 159-204.

Nielsen E. 1932. Papers from Dr. Th. Mortensen's Pacific Expedition 1914-16. LIX. Ophiurans from the Gulf of Panama, California, and the Strait of Georgia. Videnskabelige Meddelelser fra Dansk Naturhistorisk Forening 91: 241-346. 
O’Hara T.D., Hugall A.F., Thuy B., Stöhr S. \& Martynov A.V. 2017. Restructuring higher taxonomy using broad-scale phylogenomics: The living Ophiuroidea. Molecular Phylogenetics and Evolution 107: 415-430. https://doi.org/10.1016/j.ympev.2016.12.006

O’Hara T.D. \& Stöhr S. 2006. Deep water Ophiuroidea (Echinodermata) of New Caledonia: Ophiacanthidae and Hemieuryalidae. Tropical Deep Sea Benthos (Mémoires du Muséum national d'Histoire naturelle 193) 24: 33-141.

Okanishi M., O'Hara T.D. \& Fujita T. 2011. A new genus Squamophis of Asteroschematidae (Echinodermata: Ophiuroidea: Euryalida) from Australia. Zookeys 129: 1-15.

https://doi.org/10.3897/zookeys.129.1202

Paterson G.L.J. 1980. A new abyssal genus of the family Ophiuridae (Echinodermata: Ophiuroidea). Bulletin of the British Museum (Natural History), Zoology 38: 211-218.

Pennant T. 1777. Mollusca, Crustacea, Testacea. London.

Perrier E. 1893. In: Traité de zoologie. 3ser. Echinodermata: 781-864. Masson, Paris.

Peters W. 1851. Übersicht der an der Küste von Mossambique eingesammelten Ophiuren, unter denen sich zwei neue Gattungen befinden. Bericht über die zur Bekanntmachung geeigneten Verhandlungen der Königlich Preußischen Akademie der Wissenschaften zu Berlin 1851: 463-466.

Pomory C.M., Carpenter H.H. \& Winter J.H. 2011. Amphicutis stygobita, a new genus and new species of brittle star (Echinodermata: Ophiuroidea: Ophiurida: Amphilepididae) found in Bernier Cave, an anchialine cave on San Salvador Island, Bahamas. Zootaxa 2133: 50-68.

Sladen W.P. 1879a. On Astrophiura permira, an Echinoderm-Form Intermediate between Ophiuroidea and Asteroidea. Proceedings of the Royal Society of London 27: 456-457.

https://doi.org/10.1098/rspl.1878.0083

Sladen W.P. 1879b. On the structure of Astrophiura, a new and aberrant genus of Echinodermata. Annals and Magazine of natural History, Series 8 5: 410-415. https://doi.org/10.1080/00222937908679859

Smith E.A. 1877. Description of a new form of Ophiuridae from New Zealand. Annals and Magazine of Natural History, series 15 19: 305-308, XV. https://doi.org/10.1080/00222937708682145

Stöhr S. 2011. New records and new species of Ophiuroidea (Echinodermata) from Lifou, Loyalty Islands, New Caledonia. Zootaxa 3089: 1-50.

Stöhr S., Boissin E. \& Hoareau T.B. 2013. Taxonomic revision and phylogeny of the Ophiocoma brevipes group (Echinodermata, Ophiuroidea), with description of a new subgenus (Breviturma) and a new species. European Journal of Taxonomy 68: 1-26. https://doi.org/10.5852/ejt.2013.68

Stöhr S. \& Segonzac M. 2005. Deep-sea ophiuroids (Echinodermata) from reducing and non-reducing environments in the North Atlantic Ocean. Journal of the Marine Biological Association U.K. 85: 383402. https://doi.org/10.1017/S0025315405011318h

Stöhr S. \& Segonzac M. 2006. Two new genera and species of ophiuroid (Echinodermata) from hydrothermal vents in the East Pacific. Species Diversity 11: 7-32.

Studer T. 1876. Über Echinodermen aus dem antarktischen Meere und zwei neue Seeigel von den Papua-Inseln, gesammelt auf der Reise S.M.S. Gazelle um die Erde. Monatsbericht der KöniglichPreussischen Akademie der Wissenschaften zu Berlin, 1876: 452-465.

Thomson C.W. 1873. The Depths of the Sea. Macmillan and Co., London. 
Turner R.L. 1985. Microphiopholis, replacement name for Micropholis Thomas, 1966 (Ophiuroidea: Amphiuridae) NON Huxley, 1859 (Amphibia: Dissorophidae). Proceedings of the Biological Society of Washington 98: 1028-1029.

Turner R.L. \& Hallan J.K. 2011. Triplodia, replacement name for Triodia A. M. Clark, 1970 (Ophiuroidea: Amphiuridae), non Hübner, 1820 (Lepidoptera: Hepialidae). Proceedings of the Biological Society of Washington 124: 7-8. https://doi.org/10.2988/09-32.1

Tyler P.A., Paterson G.L.., Sibuet M., Guille A., Murtons B.J. \& Segonzac M. 1995. A new genus of ophiuroid (Echinodermata: Ophiuroidea) from hydrothermal mounds along the Mid-Atlantic Ridge. Journal of the Marine Biological Association U.K. 75: 977-986.

Verrill A.E. 1867. Notes on Radiata in the museum of Yale College with descriptions of new genera and species - II. Notes on the echinoderms of Panama and the west coast of America, with descriptions of a new genus. Transactions of the Connecticut Academy of Arts and Sciences 1: 251-351.

Verrill A.E. 1878. Notice of recent additions to the marine fauna of the eastern coast of North America. Nos. 1 \& 2. American Journal of Science 16: 207-215.

Verrill A.E. 1899a. Report on the Ophiuroidea collected by the Bahama expedition in 1893. Bulletin from the Laboratories of Natural History of the State University of Iowa 5: 1-86.

Verrill A.E. 1899b. North American Ophiuroidea. I.- Revision of certain families and genera of West Indian Ophiurans. II. - A faunal catalogue of the known species of West Indian Ophiurans. Transactions of the Connecticut Academy 10: 301-386.

Zittel K.A. von. 1895. Grundzüge der Paläontologie (Paläozoologie). Druck und Verlag von R. Oldenbourg, München, Leipzig. 